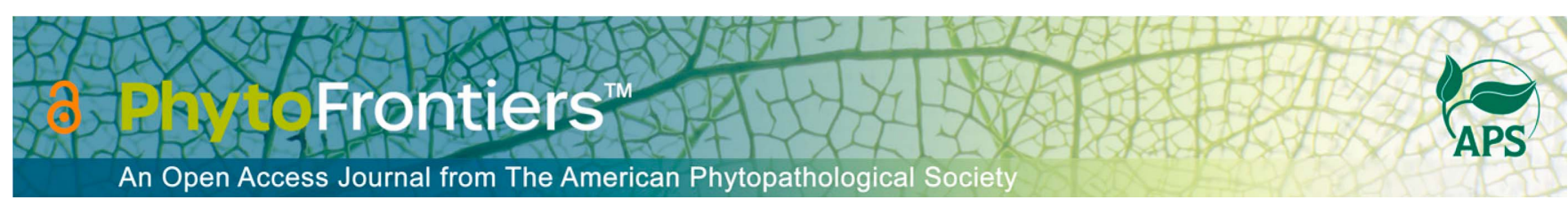

\title{
Research
}

\section{Comparative Transcriptome Analysis of Two Contrasting Maize Inbred Lines Provides Insights on Molecular Mechanisms of Stalk Rot Resistance}

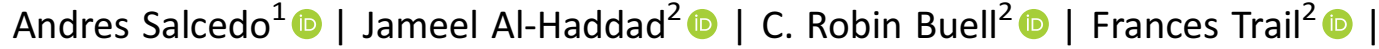 \\ Elsa Góngora-Castillo ${ }^{1,3,+}$ (D) | Lina Quesada-Ocampo ${ }^{1,+}$ (D) |
}

\begin{abstract}
${ }^{1}$ Department of Entomology and Plant Pathology, North Carolina State University, Raleigh, NC 27695 7616, U.S.A.

2 Department of Plant Biology, Michigan State University, East Lansing, MI, U.S.A.

${ }^{3}$ CONACYT-Unidad de Biotecnología. Centro de Investigación Científica de Yucatán. Calle 43 No. 130. Chuburná de Hidalgo. 97205 Mérida, Yucatán México
\end{abstract}

† Corresponding authors: E. Góngora-Castillo; elsa gongora@cicy.mx; and L. M. Quesada-Ocampo; Imquesad@ncsu.edu

Accepted for publication 30 April 2021

Author contributions

L.Q.-O., E.G.-C. conceived the concept.

L.Q.-O., E.G.-C., and A.S. designed the

experiments. L.Q.-O. and J.A. performed sample

collection and experiments. L.Q.-O. supervised

experimental work. E.G.-C. and A.S. did the

bioinformatics analyses. L.Q.-O., E.G.-C., and

A.S. did the data analysis and interpretation.

C.R.B. and F.T. performed a critical revision of the article. A.S., E.G.-C., and L.Q.-O. wrote the article.

\section{Funding}

This work was supported by the United States Department of Agriculture (USDA) Agriculture and Food Research Initiative (AFRI) competitive grant number2012-67012-19810, USDA-Agricultural Research Service under project number NC02628, and Michigan State University AgBioResearch.

E. Góngora-Castillo and L. Quesada-Ocampo contributed equally to this work and share last authorship.

$\boldsymbol{e}$-Xtra: Supplementary materials are available online.

The author(s) declare no conflict of interest.

\section{Abstract}

Maize stalk rot caused by Fusarium graminearum can lead to severe losses and accumulation of mycotoxins with detrimental effects on livestock health. Because few management strategies are available, the development of resistant varieties is considered the most cost-effective way to control the disease. However, the stalk-tissue-specific mechanisms underlying resistance to $F$. graminearum remain poorly understood, although it is believed to be strongly influenced by environmental factors. In this study, we performed a temporal transcriptome analysis of two maize inbred lines with contrasting responses to stalk rot using gene expression profiling. We observed differential downregulation of gene expression during the first 2 weeks in a resistant inbred line inoculated with F. graminearum. Timecourse gene ontology enrichment analysis suggests that resistance may be caused by a modulation of gene expression associated with redox homeostasis, hormone biosynthesis, cytoskeleton activity, and cell wall remodeling. We validated our gene expression profiling data by measuring the expression of 10 differentially expressed genes using quantitative reverse-transcription PCR. Our analyses also revealed the effect of two environmental conditions with contrasting temperatures and relative humidity on the resistant phenotype and gene expression. This research expands our knowledge of molecular events underlying resistance to stalk rot and the effect of environmental conditions on the disease interaction Our findings can be exploited for the development of resistant varieties.

Keywords: disease resistance, fungal pathogens, host-parasite interactions, plant immune responses

Maize is a staple food for millions of people and the most traded cereal crop worldwide (FAO 2020). This crop has significant socioeconomic importance due to its multifunctionality as food, livestock feed, and biofuel (FAO 2018; Nuss and Tanumihardjo 2010; Ranum et al. 2014; Shiferaw et al. 2011). The global demand for maize is 
projected to increase significantly in the next few decades (Rosegrant et al. 2017; Cairns et al. 2012). However, one of the major phytosanitary challenges to global maize production is stalk rot, caused by the hemibiotroph ascomycete Fusarium graminearum Schwabe (Goswami and Kistler 2004; Kazan et al. 2012; Lanubile et al. 2017; Ma et al. 2017). Stalk rot is a destructive disease of maize, leading to severe crop losses in temperate regions of North America as well as some parts of Europe and Asia (Beccari et al. 2019; De León and Pandey 1989; Gilbertson et al. 1985; Goswami and Kistler 2004; Miller 1994; Sutton 1982). This soilborne disease results in significant economic losses, reducing production up to $20 \%$ under severe epidemics (Li et al. 2010; Mueller et al. 2016; Quesada-Ocampo et al. 2016). Stalk rot also poses a severe threat to livestock food safety, because the fungus is capable of producing mycotoxins such as deoxynivalenol (DON), nivalenol (NIV), and zearalenone (ZEA) (Osborne and Stein 2007; Parry et al. 1995; Sutton 1982). These mycotoxins become concentrated as part of the biofuel production process and residues are used as feed, which can result in injury to livestock (Quesada-Ocampo et al. 2016). $F$. graminearum spores readily overwinter, surviving in host debris left in the field after harvest and infecting new maize stalks via rain splash, wind dispersal, or wounds made by birds or arthropods (Miller 1994; Parry et al. 1995; Sutton 1982). Maize stalk rot progresses as fungal growth within the lower end of the stalk tissue, causing discoloration from green to yellow or dark brown and necrotic lesions in the crown area under the first and second node (Koehler 1960). Internally, stalk rot destroys the pith tissue, diminishing water and photosynthate transport to the leaves and ears, resulting in reduced grain fill, lodging susceptibility, or premature plant death (Freije et al. 2016). Planting resistant varieties is a desirable strategy to control maize stalk rot because few chemical options are available for effective integrated disease management, and crop protection is not always a cost-effective option for maize growers (Parry et al. 1995; Shin et al. 2014). Because current commercial varieties either exhibit intermediate resistance or susceptibility to stalk rot (Munkvold 2003), breeding programs are focused on developing maize cultivars with resistance to stalk rot (Santiago et al. 2009). Promising natural variation in pathogen resistance and mycotoxin accumulation among maize inbred lines has been reported (Prasad et al. 2019; Quesada-Ocampo et al. 2016).

Studies suggest that stalk rot resistance can be a quantitative trait controlled by polygenes, making the identification of quantitative trait loci (QTLs) for stalk rot resistance a priority for the development of resistant cultivars (Pè et al. 1993). However, stalk rot QTL validation is strongly influenced by environmental conditions and experimental approaches (Ali et al. 2005; Butrón et al. 2015). Resistance in some genotypes has been not only associated with a few dominant genes (Lal and Singh 1984) but also mediated via recessive resistance (Ma et al. 2017) or major genes in QTL regions such as Rgsr8.1 (Chen et al. 2017), qrfg1, and qrfg2 (Yang et al. 2004; Yang et al. 2010). A gene associated with $q r f g l$ was cloned from maize chromosome 6, revealing that resistance is related to epigenetic changes on the photoperiod gene ZmCCT (Wang et al. 2017). Likewise, an auxin-regulated protein associated with $q r f g 2$ was also cloned from chromosome 1 (Ye et al. 2019), and two genes, an auxin response factor and a disease resistance protein, were found in the Rgsr8.1 QTL region (Chen et al. 2017).

The transcriptome of cereal crops interacting with $F$. graminearum has been studied using RNA-sequencing (RNA-seq) technologies on different genotypes and conditions, supported by the availability of sequence information from both the pathogen and cereal hosts (Kazan and Gardiner 2018). Despite the progress in the last few years, characterization of the defense mechanisms of maize against $F$. graminearum through differential gene expression of resistance QTLs (Harris et al. 2016; Kebede et al. 2018; Liu et al. 2016) has not revealed the defense mechanisms responsible for resistance in stalks against F. graminearum (Lanubile et al. 2017; Santiago et al. 2007). Moreover, studies fell short on addressing whether QTLs are effective in particular tissues, inbred lines, or field environmental conditions (Kazan and Gardiner 2018). Understanding the different mechanisms in maize for resistance against $F$. graminearum, including the gene regulation that underpins this resistance, will provide valuable knowledge that can be exploited to develop stalk-rot-resistant genotypes.

In this study, we evaluated the transcriptional changes in two maize inbred lines (B73 and Mp717) with contrasting resistance to stalk rot over a time course that spanned $0,2,14$, and 28 days postinoculation (dpi) with $F$. graminearum strain $\mathrm{PH}-1$. We identified differentially expressed genes (DEGs) between the susceptible (B73) and resistant (Mp717) maize inbred lines, providing insights into the molecular mechanisms behind the response to infection. We validated the transcriptome analysis with quantitative reverse-transcription PCR (qRT-PCR) using representative DEGs and evaluated their expression profiles under two environmental conditions.

\section{MATERIALS AND METHODS}

\section{Maize inbred lines and growing conditions}

Two maize inbred lines, B73 and Mp717, were evaluated for susceptibility to $F$. graminearum stalk rot and used for transcriptome analysis during infection. B73 was found to be susceptible to stalk rot in a previous study (Quesada-Ocampo et al. 2016) and has a reference genome available (Schnable et al. 2009). Mp717 has shown fungal resistance and low mycotoxin accumulation (Henry et al. 2009; Mohammadi et al. 2011; Williams and Windham 2006) and was resistant to stalk rot in a previous study (Quesada-Ocampo et al. 2016). Maize seed were surface sterilized with $2.7 \%$ sodium hypochlorite for $15 \mathrm{~min}$, rinsed with sterile water, and immediately sown on 72-square cell plastic flats (Hummert International, Earth City, MO, U.S.A.) containing soilless medium (Baccto Professional Planting Mix; Michigan Peat Company, Houston, TX, U.S.A.) as previously described (Quesada-Ocampo et al. 2016). Seedlings were grown in a greenhouse for 3 weeks, under 14-h day illumination, at a temperature setting of 26 and $22^{\circ} \mathrm{C}$ (day and night, respectively), and irrigated daily. Seedlings were transferred into 4-liter pots (Hummert International) containing a 1:1 mixture of sand/ peat-lite mixture (Redi Earth; W.R. Grace Co., Ajax, ONT, Canada). An equal number of seedlings from both inbred lines was recovered from transplant stress for 5 weeks until the V8-V9 stage in two environments: (i) a greenhouse and (ii) an environmentally controlled room (growth room) at the North Carolina State University Phytotron facility. The greenhouse was mechanically ventilated with intake fans and equipped with high-sodium lamps that provided a 14-h day photoperiod. Air temperature was in a range of 21 to $32^{\circ} \mathrm{C}$, with a daily average of $25^{\circ} \mathrm{C}$, and an average relative humidity of $60 \%$. Plants were hand irrigated as needed and fertilized with Osmocote 14-14-14 slow-release fertilizer (The Scotts Company, Marysville, $\mathrm{OH}$, U.S.A.). The growth room had $9 \mathrm{~m}^{2}$ of area by $2.13 \mathrm{~m}$ of vertical clearance and was equipped with a combination of T-12, 1,500 
ma cold white fluorescent and $100 \mathrm{~W}$ incandescent lamps. The photosynthetically active radiation at the top of the canopy was maintained at $600 \mathrm{mmol} \mathrm{m}^{-2} \mathrm{~s}^{-1}$ during a 14-h day photoperiod. The relative humidity in the room was maintained at $80 \%$ and a constant temperature of $35^{\circ} \mathrm{C}$. Plants were irrigated daily and fertilized every 2 days with North Carolina State University Phytotron Nutrient Solution (https://phytotron.ncsu.edu/ procedural-manual/).

\section{F. graminearum growing conditions and inoculation procedure}

The $F$. graminearum isolate PH-1 (NRRL31084; FGSC9075), which is the wild-type strain used in the genome sequencing project (Cuomo et al. 2007; Gaffoor et al. 2005), was used for inoculations. Isolate PH-1 was obtained from maize kernels in Michigan; it is highly pathogenic on maize and wheat, and produces high levels of DON on maize (Quesada-Ocampo et al. 2016) and DON and ZEA on wheat (Gaffoor et al. 2005). Fresh cultures of $\mathrm{PH}-1$ were obtained by transferring agar plugs from long-term stock cultures onto potato dextrose agar (PDA) (DOT Scientific, Burton, MI, U.S.A.). Cultures were grown on PDA at room temperature $\left(21 \pm 2^{\circ} \mathrm{C}\right)$ under fluorescent light for 4 days prior to inoculation, as previously described (Quesada-Ocampo et al. 2016). After removing the sheath tissue on the stalk of 12 plants of each inbred line, a 1-mm-diameter wound was made in the middle of the stalk area between the soil line and the internode above it using a sterile syringe needle to simulate insect wounding. Then, a 5-mm-diameter agar mycelial plug growing F. graminearum $\mathrm{PH}-1$ was placed face down over the wound and covered with parafilm to maintain moisture. As a noninoculated control, plants were inoculated in the same way with a sterile 5-mm-diameter agar plug of PDA.

\section{Disease evaluations and plant tissue sampling}

Disease evaluations and tissue sampling were conducted at 0 , 2, 14, and 28 dpi for noninoculated control and PH-1-inoculated plants. Three plants (inoculated and noninoculated) each of B73 and Mp717 inbred lines were rated for stalk rot symptoms at each time point and two of these plants, representative of the symptoms, were sampled for RNA-seq experiments under greenhouse conditions. All three plants at each time point and environments were used for qRT-PCR evaluation. Tissue was collected by cutting $2 \mathrm{~cm}$ below and $2 \mathrm{~cm}$ above the inoculation point after removal of parafilm and plug, dividing the sample longitudinally in two to be scored and to determine the level of infection. Tissues were immediately frozen in liquid nitrogen and stored at $-80^{\circ} \mathrm{C}$.

\section{RNA-seq}

Tissue samples were removed from the $-80^{\circ} \mathrm{C}$ freezer, lyophilized overnight, and pulverized to powder using sterile stainless-steel beads and a paint shaker. Total RNA was extracted from $100 \mathrm{mg}$ of pulverized tissue using the RNeasy Plant Mini Kit (Qiagen, Valencia, CA, U.S.A.). RNA concentration and quality were determined using the Bioanalyzer 2100 (Agilent Technologies, San Diego, CA, U.S.A.). Single-end libraries with a 50-nucleotide read length were generated using the Illumina mRNA-seq kit (Illumina, San Diego, CA, U.S.A.), pooled in multiple lanes, and sequenced with the Illumina HiSeq 2000 platform (Illumina) by the Michigan State University Research Technology Support Facility. Sequencing data were deposited in the NCBI Sequence Read Archive under Bioproject PRJNA633171.

\section{Bioinformatics analysis}

Illumina reads were checked for quality using FastQC (v 0.11.4) (Andrews 2010) and preprocessed to remove Illumina adapters and low-quality reads using Cutadapt (v 1.3) (Martin 2011), with a minimum quality of 20 and minimum read length of 30 bases. High-quality reads were mapped to the maize genome RefGen_v2 (AGPv2) using Tophat2 (v 2.1.0) (Kim et al. 2013) and updated to AGPv4 using a cross-reference v4 genome (Jiao et al. 2017). Expression abundances of the genes were estimated by running Cufflinks (v 2.2.1) (Trapnell et al. 2012). Expression values expressed in fragments per kilobase of transcript per million mapped reads (FPKM) were transformed using $\log _{2}(\mathrm{FPKM}+1)$ (Supplementary File S1) and Pearson's correlation coefficient was calculated to compare biological replicates (Supplementary Fig. S1). Two biological replicates per sample were used to identify DEGs using Cuffdiff (v 1.3.0) with $P<0.001$, false discovery rate $(\mathrm{FDR})<0.5$, and foldchange $>1.5$ (Trapnell et al. 2012). The R statistical package (R Development Core Team 2010) was used to plot expression data into heatmaps using the default options of the package gplots (Warnes et al. 2015). The Gene Ontologies (GO) were assigned to DEGs (Ashburner et al. 2000; The Gene Ontology Consortium 2017), and an enrichment test was performed using the Panther (v 14) online platform (http://geneontology.org/) to identify overrepresented functions (Mi et al. 2019; Tian et al. 2017). Ten candidate genes were selected to be evaluated by qRT-PCR for validation of the transcriptomic data and environmental effect on gene expression.

\section{Fungal load quantification and validation of DEGs by qRT-PCR}

Stalk tissue was homogenized to a fine powder using a porcelain pestle and mortar previously chilled with liquid nitrogen. Total RNA was isolated and purified using approximately $150 \mathrm{mg}$ of ground tissue and the TRIzol Plus RNA Purification Kit according to the manufacturer's instructions (Thermo Fisher, Waltham, MA, U.S.A.). To remove any traces of genomic DNA, total RNA was treated with DNAse I amplification grade $(1 \mathrm{U} / \mu \mathrm{l})$ as instructed by the manufacturer (Thermo Fisher). Total RNA integrity and quantity were evaluated using the 2100 Bioanalyzer RNA 6000 Kit (Agilent Technologies, Santa Clara, CA, U.S.A.) and DeNovix DS-11 (Denovix, Wilmington, DE, U.S.A.). cDNAs were synthesized from each sample using approximately $0.8 \mu \mathrm{g}$ of total RNA using SuperScript III First-Strand Synthesis SuperMix for qRT-PCR following the manufacturer's instructions (Thermo Fisher).

Internal reference genes for qRT-PCR were selected based on the five most stable expressed transcripts under different experimental conditions described by Manoli et al. (2012). The expression stability of the five candidate reference genes in maize tissue at different time points and treatments was assessed using NormFinder for R (v 5) (Andersen et al. 2004), and the two more stable genes were used for all relative expression quantification. Relative fungal biomass was estimated using qRT-PCR by measuring the relative expression of $F$. graminearum glyceraldehyde-3-phosphate dehydrogenase $(G A P D H)\left(F G S G_{-} 16627\right)$, as described previously (Harris et al. 2016). Specific primers for DEGs were designed by PrimerBLAST (Ye et al. 2012) using the B73 RefGen_v4 (Jiao et al. 2017) (Supplementary Table S1). The qRT-PCR assays were 
performed in a CFX96 Touch real-time PCR detection system (Bio-Rad, Hercules, CA, U.S.A.). Reactions were prepared containing $5 \mu$ of $2 \times$ PowerUp SYBR Green Master Mix (Thermo Fisher), $1 \mu \mathrm{l}$ of cDNA (1:5 dilution), and $250 \mathrm{nM}$ gene-specific primers in a final volume of $10 \mu$. The following thermal profile was used for all PCR assays: $50^{\circ} \mathrm{C}$ for $2 \mathrm{~min}, 95^{\circ} \mathrm{C}$ for $2 \mathrm{~min}$, and 40 cycles of $95^{\circ} \mathrm{C}$ for $15 \mathrm{~s}$ and $60^{\circ} \mathrm{C}$ for $1 \mathrm{~min}$. Two technical replications were performed for each time point. Primer amplification efficiency for every primer set was calculated using serial dilutions of cDNA (Pfaffl 2004). Cycle threshold values were used to calculate the relative change in gene expression relative to the two most stable reference genes and nontreated control by using the $2^{-\Delta \Delta \mathrm{Ct}}$ method (Livak and Schmittgen 2001). Data were transformed to $\log _{2}$ and outliers were identified and manually discarded. Analysis was performed with the proc GLIMMIX procedure of SAS software (SAS Institute, Inc., Cary, NC, U.S.A.) and ggscatterstat in R (R Development Core Team 2010). We evaluated the correlation between mean expression values of RNA-seq and qRT$\mathrm{PCR}$, and the differences in the relative mean expression at each time point and between environments were estimated using two-way analysis of variance (ANOVA) followed by least significant difference (LSD) post hoc analysis.

\section{RESULTS}

\section{Disease severity under $F$. graminearum infection}

Two maize inbred lines previously characterized under greenhouse conditions as resistant (Mp717) and susceptible (B73) to stalk rot caused by $F$. graminearum (Quesada-Ocampo et al. 2016) were inoculated with $F$. graminearum $\mathrm{PH}-1$ strain and evaluated at $0,2,14$, and 28 dpi under both growth room and greenhouse conditions. The first symptoms associated with stalk rot disease were visible at $2 \mathrm{dpi}$ and progressed at different rates depending on the maize inbred line and environment. Susceptible plants displayed a black ring of discolored tissue surrounding the punctures and expanding through the stem. These symptoms were evident for both inbred lines inoculated with $F$. graminearum under growth room conditions. Under greenhouse conditions, B73 displayed susceptible symptoms in contrast to $\mathrm{Mp} 717$, which only displayed symptoms related to wounding due to the inoculation procedure (Fig. 1A and B).

\section{Phenotypic stability and fungal biomass accumulation in maize inbred lines under greenhouse and growth room environments}

Transversal sections of the maize stalk showed differences in the severity of the disease between the two environmental conditions (Fig. 1B). Stalk tissues surrounding the wound site turned pale brown by 2 dpi (data not shown). Stalk tissue became more necrotic and dark brown in color at 14 and 28 dpi, increasing the affected area. Evident resistance to stalk rot was observed in the Mp717 inbred line only under greenhouse conditions, because the growth room conditions appeared more favorable for stalk rot disease development (Fig. 1B). In contrast, both inbred lines B73 and Mp717 displayed severe damage under growth room conditions, where the pathogen caused dark discoloration on inoculated tissues. To provide an estimation of fungal growth in addition to disease severity, we estimated fungal biomass using the $F$. graminearum GAPDH gene (Fig. 1C), which is expressed constitutively through the
A

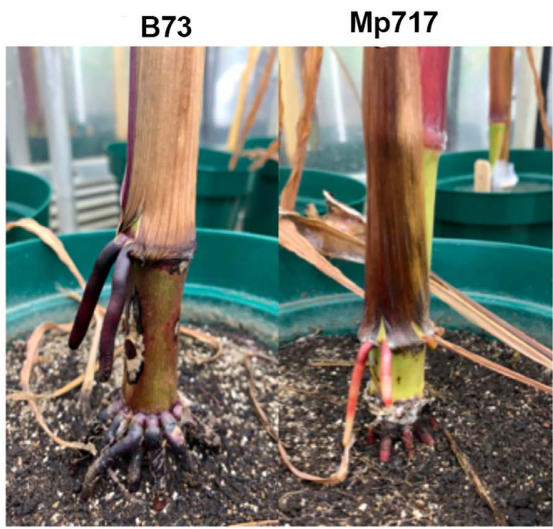

B

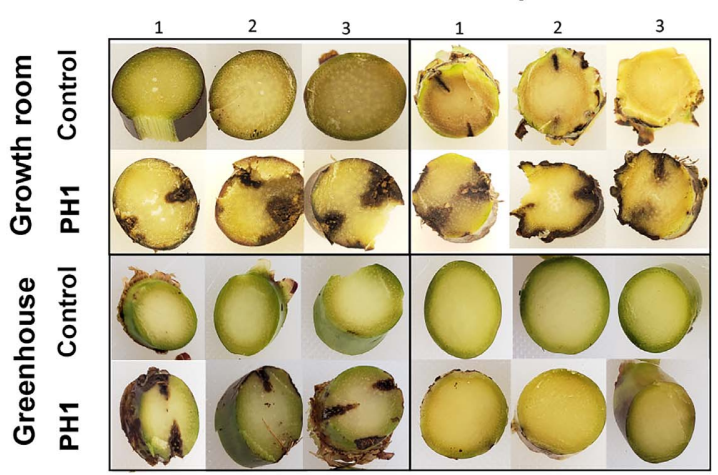

C

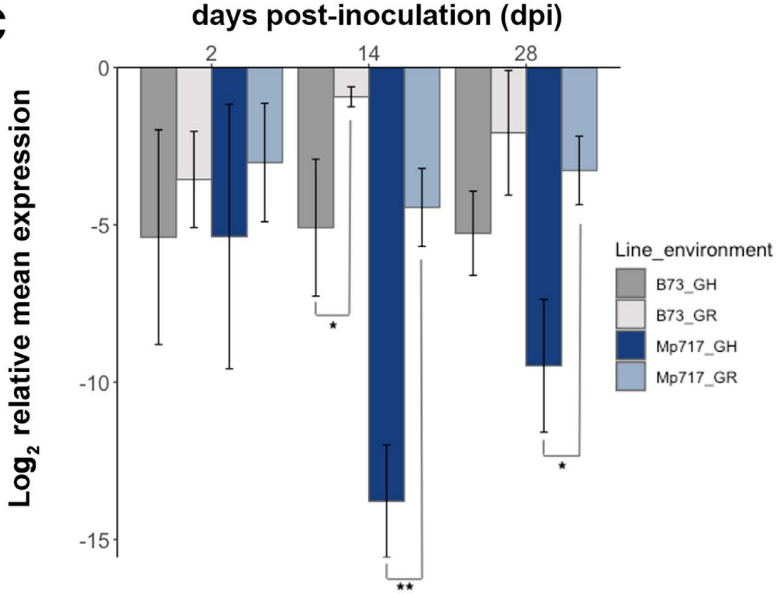

FIGURE 1

Phenotypic variation of stalk rot disease caused by Fusarium graminearum $\mathrm{PH} 1$ infection. A, Stalk phenotypes from maize inbred lines Mp717 (resistant) and B73 (susceptible) 14 days postinoculation (dpi) under greenhouse conditions. B, Stalk cross sections of Mp717 (resistant) and B73 (susceptible) 28 dpi with F. graminearum $\mathrm{PH} 1$ and noninoculated control under greenhouse and growth room conditions. Every cross section number (1 to 3 ) represents a biological replication. C, F. graminearum $\mathrm{PH} 1$ relative fungal biomass estimated using quantitative reverse-transcription PCR. The relative expression of the fungal GAPDH gene was evaluated at 2,14 , and 28 dpi using as reference the average expression of the maize membrane protein PB1A10.07c and folylpolyglutamate synthase. Bars represent the relative mean expression (three biological replicates) calculated using the $2^{-\Delta \Delta C t}$ method. Error bars represent standard deviations of the mean. A two-way analysis of variance test followed by Tukey's post hoc test was performed to check significant differences between inbred lines and environmental conditions (* and ** indicate $P<0.05$ and 0.001 , respectively). $\mathrm{GR}=$ growth room and $\mathrm{GH}=$ greenhouse. 
fungal life cycle (Boedi et al. 2016). At 2 dpi, the biomass in both environments and inbred lines were similar; however, at 14 and $28 \mathrm{dpi}$, the $F$. graminearum biomass was significantly less $(P<0.05)$ in the resistant inbred line Mp717 grown under greenhouse conditions, compared with other treatments (Fig. 1C). Significant differences in biomass accumulation were detected at 14 dpi on the susceptible B73 line under both environmental conditions, with growth room conditions being more conducive for $F$. graminearum proliferation.

\section{Transcriptome analysis of control and inoculated maize inbred lines Mp717 and B73}

To characterize the changes in transcriptome during infection with $F$. graminearum, RNA-seq libraries were prepared from total RNA extracted from stalk tissue from B73 and Mp717 at 2, 14, and 28 dpi. RNA-seq libraries were prepared using two biological replicates of inoculated and noninoculated stalks obtained from greenhouse conditions. The Illumina HiSeq 2000 platform yielded a total of 1,025,931,969 reads. After adapter removal and filtering for quality, 947,900,277 clean reads were used for analysis. The average number of reads per sample ranged from approximately 26 to 48 million reads (Supplementary Table S2). Cleaned reads were mapped to the maize genome RefGen_v4 (AGP v4) and expression abundances of genes were estimated in terms of FPKM. Data files are available at https://figshare.com/projects/Comparative_transcriptome_ analysis_of_two_contrasting_maize_inbred_lines_provides_insights_ on_molecular_mechanisms_of_stalk_rot_resistance/101711 and codes are available at https://github.com/gongoracastillolab/ RNA-seq. Biological replicates were analyzed by Pearson's correlation coefficient (Supplementary File S; Supplementary Fig. S1). The percentage of mapped reads to the maize genome ranged from 93 to $97 \%$ for B73 and 88 to $91 \%$ for Mp717, confirming the good quality of the reads (Supplementary Table S2).

The analysis of expression abundances for each transcriptome revealed changes in gene expression profiles (Fig. 2; Supplementary File S2). The heatmap plot in Figure 2 showed differences in gene expression for several clusters of genes between the noninoculated plants (Mp717 control and B73 control), suggesting differences in gene regulation not related to infection between these two maize inbred lines. As expected, differences in the expression profiles of the two maize inbred lines inoculated with $F$. graminearum were observed (Mp717-PH1 and B73-PH1) at 2, 14, and 28 dpi. However, the heatmap suggests that the $F$. graminearum infection does not induce major differences in expression between noninoculated controls and PH1inoculated plants of the same inbred line (Mp717 control versus Mp717-PH1; B73 control versus B73-PH1) (Fig. 2).

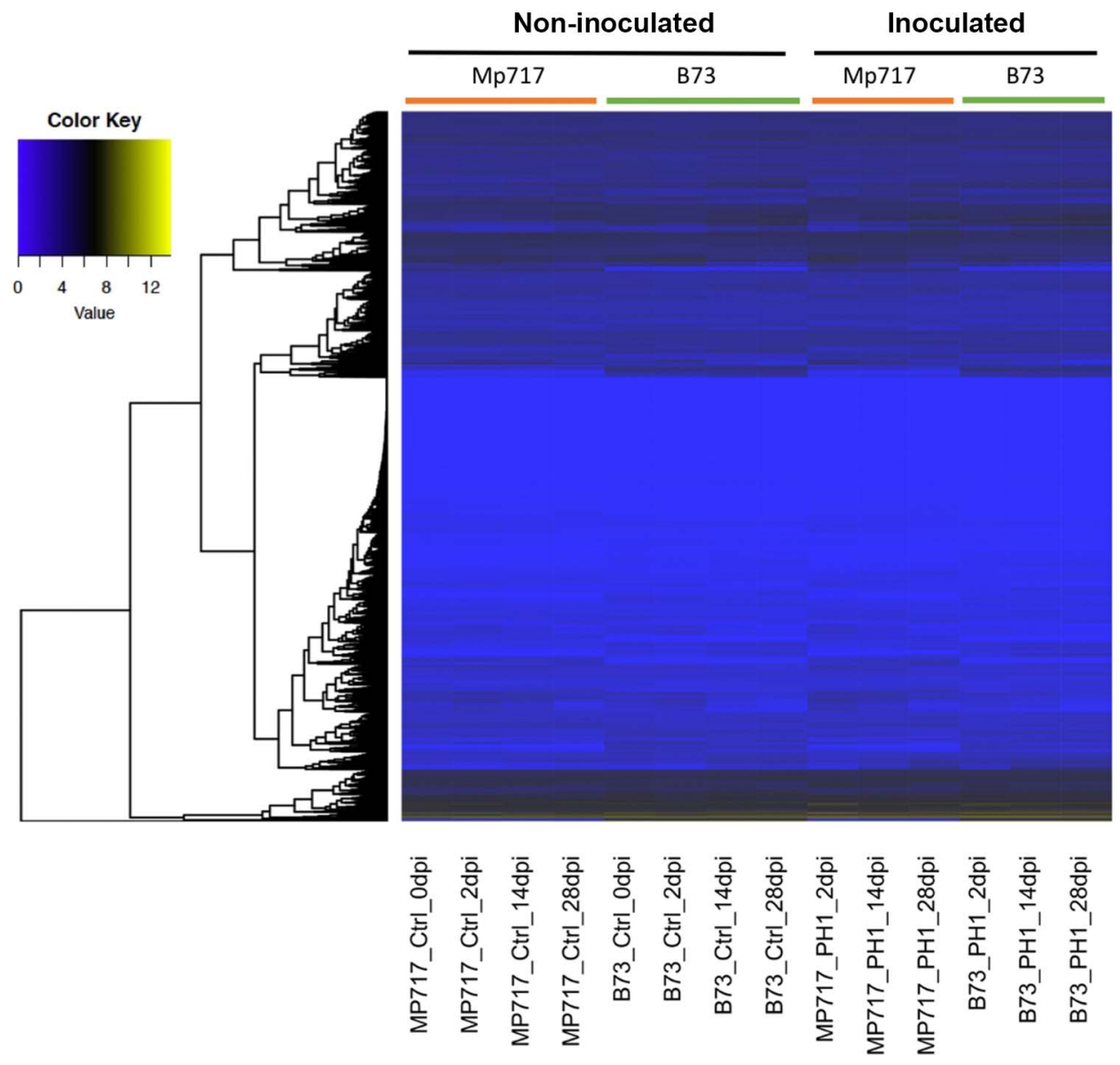

FIGURE 2

Heat map illustrating the hierarchical clustering results of RNA-sequencing data in noninoculated control (Crtl) and Fusarium graminearum PH1-inoculated maize inbred lines Mp717 (resistant) and B73 (susceptible). The dendrogram on the $\mathrm{x}$-axis represents the hierarchical clustering of genes as determined by Euclidean distance and the samples in the y-axis. The heat map shows a false color representing the $\log _{2}$ gene expression value (fragments per kilobase of transcript per million mapped reads) that indicates the differential expression profiles at different days postinoculation (dpi). 


\section{Differential gene expression analysis}

Differential gene expression analyses were performed with four different comparisons between the maize inbred lines at 2, 14, and 28 dpi: (I) susceptible-noninoculated versus susceptible-PH1 inoculated (B73 versus B73-PH1), (II) resistant-noninoculated versus resistant-PH1 inoculated (MP717 versus Mp717-PH1), (III) susceptible-noninoculated versus resistant-noninoculated (B73 versus Mp717), and (IV) susceptible-PH1 inoculated versus resistant-PH1 inoculated (B73-PH1 versus Mp717-PH1) (Table 1; Supplementary File S2). The results of this analysis revealed a larger number of DEGs in B73 compared with Mp717 (comparisons I and II) due to inoculation with PH-1. In comparison I, 114 DEGs were observed at $2 \mathrm{dpi}$; of these, 98 were upregulated and 16 were downregulated; at $14 \mathrm{dpi}$, the number of DEGs increased to 404; of these, 340 were upregulated and 64 downregulated; and, at $28 \mathrm{dpi}$, the number of DEGs identified rose to 655, of which 495 were upregulated and 160 were downregulated (Table 1). Surprisingly, no DEGs were observed in the resistant inbred Mp717 noninoculated versus PH1 inoculated (comparison II) at 2 and $14 \mathrm{dpi}$, with only 121 genes differentially expressed at 28 dpi; of these, 119 were upregulated and 2 were downregulated. As expected, a large number of genes were differentially expressed when comparing both inbred lines under control conditions (comparison III); 973, 3,882, and 4,968 DEGs were observed at 2, 14, and $28 \mathrm{dpi}$, respectively, in comparison of noninoculated plants. Of these, the majority were downregulated at 2 and $14 \mathrm{dpi}$ (65 and $57 \%$, respectively), with $66 \%$ upregulated at $28 \mathrm{dpi}$. These results are consistent with the overall expression profiles shown in Figure 2, where the majority of gene expression differences were due to genotypic differences between B73 and Mp717 maize inbred lines rather than the presence of the pathogen.

The numbers of DEGs obtained when comparing B73-PH1 and Mp717-PH1 (comparison IV) were 2,458 at $2 \mathrm{dpi}, 3,994$ at $14 \mathrm{dpi}$, and 3,367 at $28 \mathrm{dpi}$. Of these, 21,34 , and $48 \%$ were upregulated, and 79, 66, and 52\% were downregulated at 2, 14 , and $28 \mathrm{dpi}$, respectively. Due to noninoculated maize inbred lines showing a large number of DEGs (comparison III) that were not related to the $F$. graminearum $\mathrm{PH}-1$ infection response, those genes were removed from the DEG dataset for comparison IV (Table 1; Fig. 3). Thus, 136, 678, and 964 upregulated genes and 484, 1,350, and 887 downregulated genes at 2, 14, and 28 dpi, respectively, were removed. The number of up- and downregulated genes that were used for downstream analysis were 375 and 1,463 at 2 dpi, 587 and 1,064 at 14 dpi, and 556 and 697 at 28 dpi, respectively (Fig. 3).

\section{Maize genes involved in the response to $F$. graminearum $\mathrm{PH}-1$ infection}

A GO enrichment test was performed to identify gene functions of DEGs related to $F$. graminearum infection in the susceptible B73 and resistant Mp717 inbred lines. The upregulated and downregulated datasets in comparisons I, II, and IV at 2, 14, and 28 dpi were analyzed using the Panther online webtool (http:// geneontology.org) (Mi et al. 2019) and classified into the two main GO categories: molecular function (MF) and biological process (BP) (Figs. 4 and 5; Supplementary File S3).

The results of MF enrichment for comparison I (B73 versus B73-PH1) revealed an increase in the number of MF terms $(21,39$, and $76 \mathrm{MF}$ terms, FDR $\leq 0.05)$ at 2,14 , and $28 \mathrm{dpi}$, respectively, following the $F$. graminearum infection progress on B73 (Supplementary File S3; Fig. 4). Most of the upregulated MF terms were associated with catalytic activity function (GO:0003824), binding (GO:0005488), and oxido-reductase activity (GO:0016941) (Fig. 4). No enriched GO terms for downregulated genes were detected at 2 and 14 dpi for comparison I (B73 versus B73-PH1) (Supplementary File S3). Most downregulated genes at 28 dpi included MFs associated with transporter activity (GO:0022857 and GO:0005215) and peptidase activity (GO:0070011 and GO:0008233) (Supplementary File S3). The results of BP enrichment for comparison I

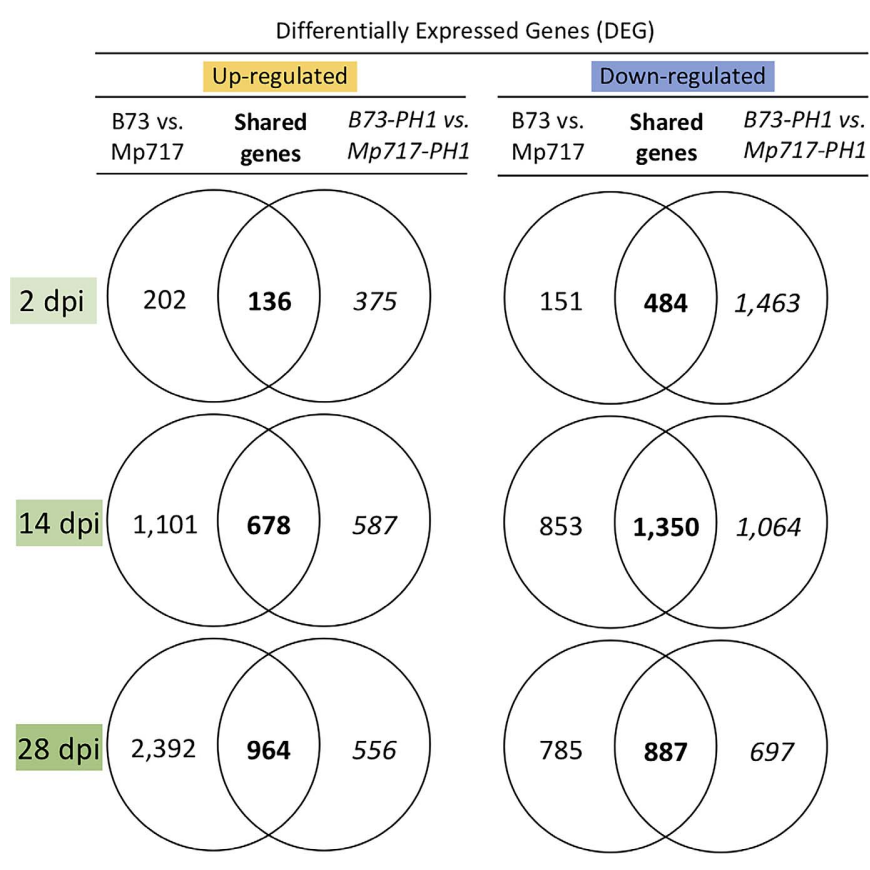

FIGURE 3

Venn Diagram displaying the number of differentially expressed overlap and unique genes in noninoculated and Fusarium graminearum PH1-inoculated maize inbred lines Mp717 and B73. Upregulated $=$ number of genes that were identified as upregulated in noninoculated and $F$. graminearum-inoculated maize inbred lines and downregulated = number of genes that were identified as downregulated in noninoculated and $F$. graminearum-inoculated maize inbred lines. Genes in the intersection (shared genes) were excluded for the downstream analyses.

TABLE 1

Number of differentially expressed genes in maize inbred lines Mp717 (resistant) and B73 (susceptible) through four comparisons ${ }^{\mathrm{a}}$

\begin{tabular}{lcccc}
\hline Days $^{\mathrm{b}}$ & $\begin{array}{c}\text { B73 versus B73-PH1 } \\
\text { (comparison I) }\end{array}$ & $\begin{array}{c}\text { Mp717 versus Mp717-PH1 } \\
\text { (comparison II) }\end{array}$ & $\begin{array}{c}\text { B73 versus Mp717 } \\
\text { (comparison III) }\end{array}$ & $\begin{array}{c}\text { B73-PH1 versus Mp717- } \\
\text { PH1 (comparison IV) }\end{array}$ \\
\hline 2 & $114(98 \mathrm{u} \mid 16 \mathrm{~d})$ & 0 & $973(338 \mathrm{u} \mid 635 \mathrm{~d})$ & $2,458(511 \mathrm{u} \mid 1,947 \mathrm{~d})$ \\
14 & $404(340 \mathrm{u} \mid 64 \mathrm{~d})$ & 0 & $3,882(1,679 \mathrm{u} \mid 2,203 \mathrm{~d})$ & $3,679(1,265 \mathrm{u} \mid 2,414 \mathrm{~d})$ \\
28 & $655(495 \mathrm{u} \mid 160 \mathrm{~d})$ & $121(119 \mathrm{u} \mid 2 \mathrm{~d})$ & $4,968(3,296 \mathrm{u} \mid 1,672 \mathrm{~d})$ & $3,044(1,460 \mathrm{u} \mid 1,584 \mathrm{~d})$ \\
\hline
\end{tabular}

${ }^{a} P$ value $<0.001$; fold-change $>1.5$; false discovery rate $<0.05 ; \mathrm{u}=$ upregulated genes; and $\mathrm{d}=$ downregulated genes.

${ }^{\mathrm{b}}$ Days postinoculation. 
(B73 versus B73-PH1) showed that most upregulated genes at 2 and $14 \mathrm{dpi}$ were related to the oxidation-reduction process (GO:0055114), also present at 28 dpi (Fig. 4; Supplementary File S3). Downregulated genes for comparison I (B73 versus B73-PH1) occurred at $28 \mathrm{dpi}$ and BPs were mostly associated with transmembrane transport (GO:0055085) (Supplementary File S3).

Significant GO enrichments for comparison II (Mp717Mp717PH1) were obtained only at $28 \mathrm{dpi}$ and only for upregulated genes (Supplementary File S3; Fig. 4). At this time point, 310 upregulated genes were grouped into $22 \mathrm{MF}$ terms (Supplementary File S3). Most of the genes were associated with catalytic activity (GO:0003824), binding (GO:0005488), and oxido-reductase activity (GO:0016491) (Fig. 4). For the same comparison II, 20 BP terms were enriched in the resistant inbred Mp717 at $28 \mathrm{dpi}$ and most upregulated genes were related to oxidation-reduction processes (GO:0055114) (Fig. 4). No BP-enriched downregulated terms were detected at 28 dpi for comparison II.

For comparison IV (B73-PH1 versus Mp717-PH1), the upregulated genes on Mp717 were grouped into 7, 12, and $16 \mathrm{MF}$ terms at 2, 14, and $28 \mathrm{dpi}$, respectively (Supplementary File S3; Fig. 5). At 2, 14, and 28 dpi, genes were mostly related to catalytic activity (GO:0003824) and hydrolase activity (GO:0016787) (Fig. 5). Interestingly, MF-enriched terms for downregulated genes mostly occurred at 2 and $14 \mathrm{dpi}$, with no enriched terms at $28 \mathrm{dpi}$, and most genes were related to catalytic activity (GO:0003824) (Fig. 5). Overrepresented BP terms for comparison IV (B73-PH versus Mp717-PH1) mostly occurred at
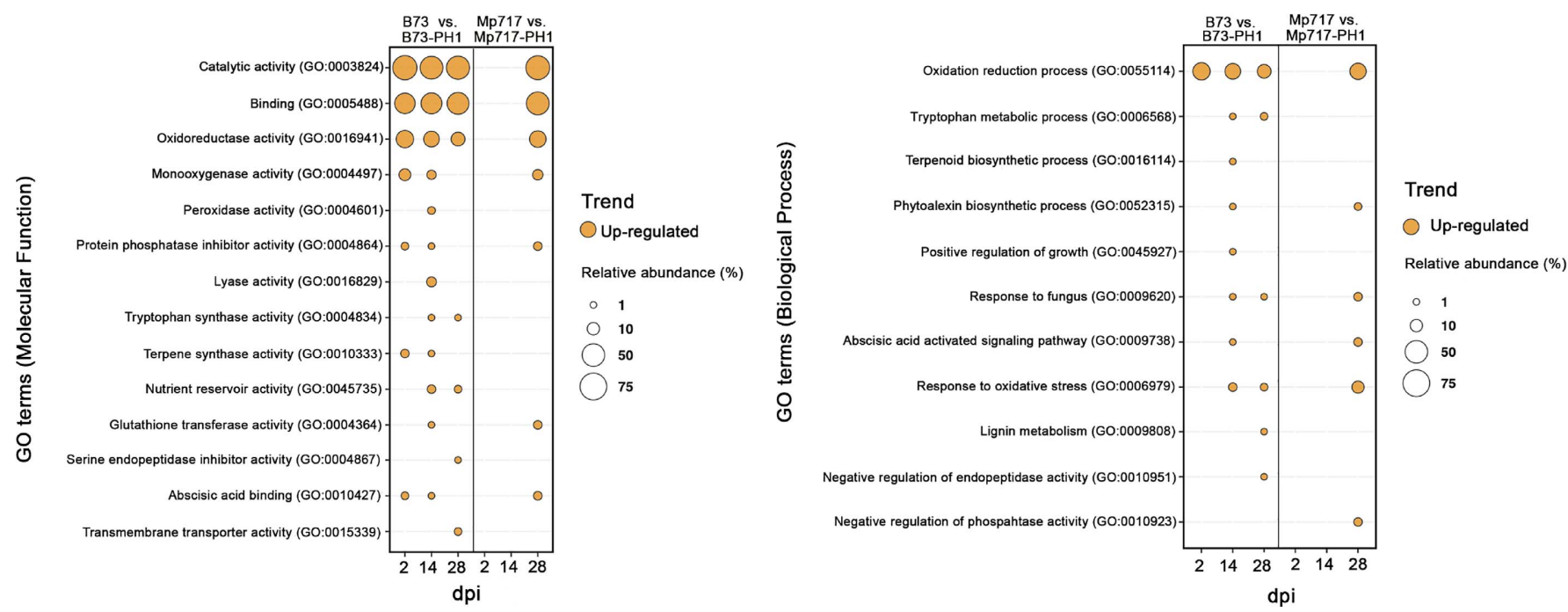

FIGURE 4

Significantly enriched Gene Ontology (GO) terms associated with differentially expressed genes during Fusarium graminearum strain PH1 infection. Stalk-rot-resistant maize inbred line Mp717 and susceptible B73 were inoculated by F. graminearum under greenhouse conditions. The area of the circle represents the relative abundance of genes associated with the representative enriched $\mathrm{GO}$ terms differentially expressed on inoculated tissue; $\mathrm{dpi}=$ days postinoculation. For simplicity, only representative upregulated GO terms from noninoculated versus $\mathrm{PH} 1$ inoculated were considered.
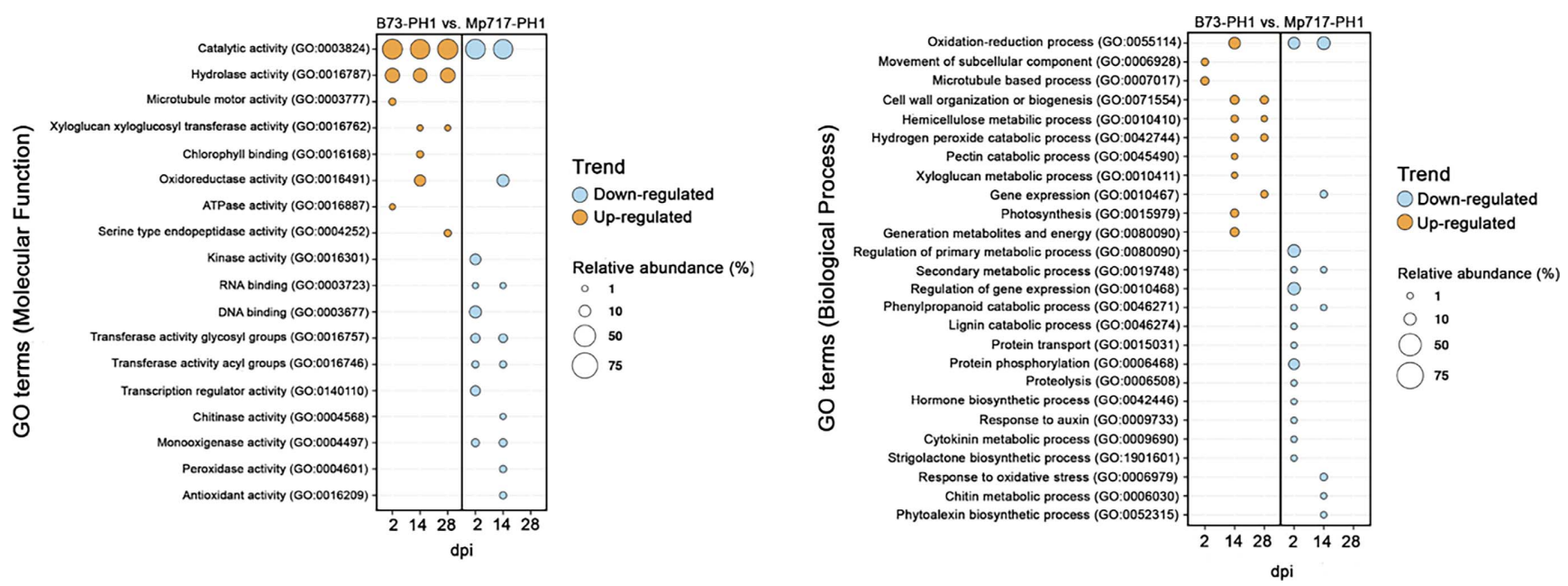

FIGURE 5

Significantly enriched Gene Ontology (GO) terms associated with differentially expressed genes during Fusarium graminearum infection. Stalk-rot-resistant maize inbred line Mp717 and susceptible B73 were inoculated by F. graminearum under greenhouse conditions. The area of the circle represents the relative abundance of genes associated with the representative enriched GO terms differentially expressed on $\mathrm{Mp} 717$; dpi = days postinoculation and $\mathrm{PH} 1=$ F. graminearum strain $\mathrm{PH} 1$. 
14 and $28 \mathrm{dpi}$, and genes were related to oxidation-reduction (GO:0005488) and other metabolic processes (Fig. 5). As observed for MF terms, no BP terms were enriched for downregulated genes at $28 \mathrm{dpi}$ and, for 2 and $14 \mathrm{dpi}$, most genes were related to oxidation-reduction (GO:0005488) and other metabolic processes (Fig. 5).

\section{Validation of DEGs in maize involved in response to $F$. graminearum $\mathrm{PH}-1$ infection}

To validate our set of DEGs and the effect of environmental conditions (greenhouse and growth room) on gene expression, the expression profiles of 10 genes with overrepresented GO categories related to disease response were evaluated using qRT-PCR (Supplementary Tables S1 and S3). Primer efficiencies ranged from 85 to $116 \%$ and PCR product specificities were evaluated by melting curve analysis and agarose gel electrophoresis (data not shown). We identified the most suitable reference genes for our study using NormFinder (Andersen et al. 2004), which showed the membrane protein PB1A10.07c (GRMZM2G018103_T01) and folylpolyglutamate synthase (GRMZM2G393334_T01) as the most stable genes, with an M value of 0.26 considering all treatments. The relative expression fold change of each DEG was calculated at 2, 14, and 28 dpi and normalized with the expression of noninoculated plants $\left(2^{-\Delta \Delta \mathrm{Ct}}\right.$ method) (Fig. 6). The Pearson's correlation coefficient between the mean expression of DEGs on two platforms (qRT-PCR versus RNA-seq) for greenhouse plants was $P=0.69, P<0.001$ (Supplementary Fig. S2), suggesting a strong correlation between these two methods for gene transcript quantification.

To identify whether the greenhouse environment and growth room environment had a significant effect on gene expression, the relative expression data from qRT-PCR analysis was analyzed using a two-way ANOVA, and LSD was used to separate the means. Significant differences were observed between the two environments and inbred lines. At 2 dpi, the mean expression of four genes, including UDP-glucosyltransferase (Zm00001d006140), phenylalanine ammonia lyase 3 (Zm00001d051161), ethylene (ET)-responsive transcription factor 15 (Zm00001d019475), and chitinase 2 (Zm00001d036370), was significantly $(P<0.05)$ lower on B73 and Mp717 grown under greenhouse compared with growth room conditions. A noticeable reduction of gene expression was observed at 14 dpi only in the resistant Mp717 on 6 of 10 genes analyzed $(P<0.05)$ under greenhouse conditions: (CYP72A15) cytochrome P450 family 72 (Zm00001d044147), multicopper oxidase type 1 (Zm00001d023617), flavone 3'-Omethyltransferase 1 (Zm00001d048087), pathogenesis-related protein 7 (Zm00001d028815), pathogenesis-related protein 10 (Zm00001d028816), and peroxidase 12 (Zm00001d042022). This strong reduction in gene expression at $14 \mathrm{dpi}$ was followed by a significant increase of the mean gene expression of those eight genes at 28 dpi (Fig. 6).

\section{DISCUSSION}

\section{At early stages of $F$. graminearum infection, the Mp717 transcriptome showed downregulation of gene expression}

DEGs associated with the response to $F$. graminearum (comparison IV: Mp717-PH1 versus B73-PH1) showed significant gene downregulation at 2 and 14 dpi on resistant Mp717 (Fig. 3). This suggests that a temporal regulation of gene expression plays an important role in conferring resistance to stalk rot in this inbred line and confirms the influence of the host genetic background on response to infection (Springer et al. 2009). In several pathosystems, resistant genotypes display an early and strong upregulation of defense genes shortly after infection with Fusarium spp. Such early responses have been observed in banana (Zhang et al. 2019), flax (Dmitriev et al. 2017), melon (Sebastiani et al. 2017), and wheat (Bernardo et al. 2006; Ding et al. 2011). For maize, our results contrast with those of Liu et al. (2016), who showed that, in three near-isogenic lines with resistance to stalk rot, more genes were upregulated at early stages of infection. However, similar to our results, Kebede et al. (2018) found a large number of downregulated genes at 2 dpi on resistant maize inbred lines to ear rot caused by $F$. graminearum.

\section{Gene expression and GO enrichment analysis suggests that stalk rot resistance is associated with temporal modulation of gene expression}

GO enrichment analysis for MF and BP categories identified processes associated with the Mp717 resistance response. Comparison of resistant (Mp717) and susceptible (B73) inbred lines under inoculated (PH1) and noninoculated (control) conditions (comparison I, B73 versus B73-PH1, and comparison II, Mp717 versus Mp717-PH1) showed that inbred lines had a differential temporal response to $F$. graminearum infection (Figs. 4 and 5; Supplementary File S3). The susceptible B73 response was characterized mainly by overexpression of genes related to redox metabolism at all time points evaluated, contrasting with the overexpression of some of those genes at $28 \mathrm{dpi}$ in resistant Mp717. The accumulation of reactive oxygen species (ROS) resulting from oxidation-reduction processes implies successful pathogen detection (Torres et al. 2006; Waśkiewicz et al. 2014), antimicrobial defense response (Chaouch et al. 2012; Torres and Dangl 2005), activation of signaling pathways (Choudhury et al. 2017; Gilroy et al. 2016), cell wall strengthening (Kärkönen and Kuchitsu 2015), and response to mechanical wounding (Tronchet et al. 2010). These findings suggest that resistance observed on Mp717 is based on a temporal modulation of gene expression of genes involved in stress response and basal plant metabolism, which has been observed in resistance to multiple pathogens (Alfano et al. 2007, Lewis et al. 2015; Wang et al. 2019).

\section{Mp717 resistance is associated with downregulation of oxide-reduction processes, hormone biosynthesis, and a delayed biotic stress response}

During the first 2 weeks of $F$. graminearum infection on $\mathrm{Mp} 717$, there was reduction in transcriptional activity of several genes, including those that code for glycosyltransferases and acyltransferases associated with diversification of secondary metabolism compounds (Fig. 5; Supplementary File S3). Acylation occurs during production of several types of secondary metabolites in multiple metabolic pathways, including phenylpropanoids (Mugford and Milkowski 2012), which are building blocks for multiple defense-related compounds (Bontpart et al. 2015). In parallel with reduction of defense response compounds, there was also a reduction of secretion of antimicrobial compounds, shown by the downregulation of the Exo70 exocyst subunit. The exocyst, a multiprotein complex playing an essential role in many biological processes of immunity, growth, and development, facilitates the secretion of Golgi apparatusderived vesicles toward the plasma membrane (Munson and Novick 2006). 


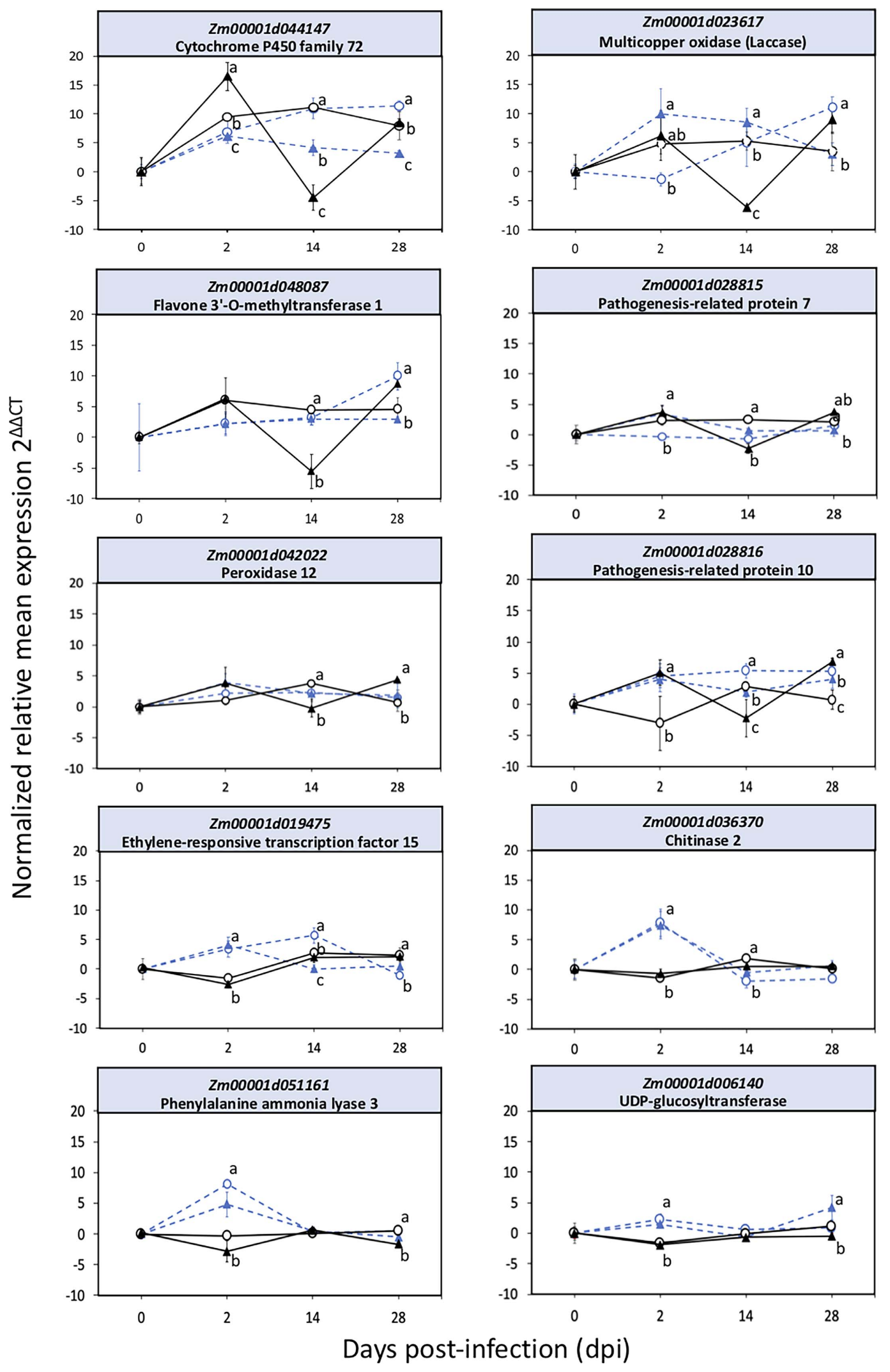

Mp717 Greenhouse -O- B73 Greenhouse - - - Mp717 Growth room - - O- B73 Growth room

FIGURE 6
Time-course of normalized relative expression level of selected differentially expressed genes in stalk-rot-resistant maize inbred line Mp717 and susceptible B73. Plants were subject to inoculation with Fusarium graminearum strain $\mathrm{PH} 1$ under greenhouse (black solid lines) and growth room conditions (blue dashed lines). Relative expression was estimated using the $2^{-\Delta \Delta C t}$ method, using as reference the average expression of the maize membrane protein PB1A10.07c and folylpolyglutamate synthase and normalized with the mean expression on noninoculated tissue. Error bars indicate standard deviation of three independent biological replicates. Letters indicate significant differences calculated from the least significant difference post hoc test. 
Differential downregulation of chitinases during the first 2 weeks of $F$. graminearum infection on Mp717 also suggests a reduction of the immune response. Chitinases hydrolyze the $\mathrm{N}$-acetylglucosamine polymer chitin, a structural component of several pathogens (Javed et al. 2013). Chitin oligosaccharide recognition further activates pathogen-associated molecular pattern (PAMP)-triggered immunity (Zipfel and Felix 2005), increasing the defense response against a wide range of pathogens (Ali et al. 2018). The immune response may also be attenuated during early interaction of Mp717 with $F$. graminearum by reduction of ATP-binding cassette transporters type $\mathrm{G}$ and C. These transporters modulate the transport of signaling or defensive compounds and are rapidly upregulated when plants are treated with fungal PAMPs such as chitins (Banasiak et al. 2013). Several receptor-like kinases were also downregulated at early stages of infection on Mp717 stalk tissue; these proteins function as sensors of PAMPs (Boller and Felix 2009) but also regulate several biological processes, including plant growth and development (Lin et al. 2013).

A notable increase in the transcription of serine hydrolases was observed at $28 \mathrm{dpi}$ on Mp717. These enzymes include a large group of proteases, lipases, esterases, and transferases involved in development, immunity, and other physiological functions (Kaschani et al. 2009). The upregulation of proteases in Mp717 at 28 dpi would have a broader effect because different families of proteases are involved in virtually every immunity process (Balakireva and Zamyatnin 2018). Interestingly, there was differential upregulation of subtilisins, a serine-type protease that would act as a receptor for defense signaling pathways (Figueiredo et al. 2014), providing a basal surveillance system. It has been reported that their promoters are induced by salicylic acid (SA) (Jordá and Vera 2000) and their inhibition can reduce the plant defense response by increasing susceptibility to pathogens (Gindro et al. 2012).

Transcriptomic evidence suggests a differential modulation of hormone distribution on Mp717 under F. graminearum infection. Phytohormones such as SA, jasmonic acid (JA), ET, gibberellic acid (GA), and abscisic acid (ABA) are typically activated to respond to pathogen invasion but there is a penalty for plant growth and reproduction; thus, hormones are carefully modulated (López et al. 2008). Several genes that code for key enzymes involved in hormone synthesis were differentially downregulated at $2 \mathrm{dpi}$ on Mp717. These genes included the copalyl diphosphate synthase that catalyzes the synthesis of GA (Otomo et al. 2004), allene oxide cyclase and 12-oxo-phytodienoic acid reductase in the synthesis of JA (Acosta et al. 2009; Taki et al. 2005), and 1-aminocyclopropane-1-carboxylate oxidase in the synthesis of ET (Vriezen et al. 1999). Interestingly, members of the cytochrome P450 monooxygenase ABA 8'-hydroxylase were downregulated during $F$. graminearum infection on Mp717 at 2 and $14 \mathrm{dpi}$, while aldehyde oxidase 3, the last step in ABA biosynthesis (Seo et al. 2000), was upregulated at $28 \mathrm{dpi}$ in Mp717. The hydroxylases catalyze the first step in the oxidative degradation of the ABA (Krochko et al. 1998; Zeevaart and Creelman 1988), modulating the ABA content (Millar et al. 2006).

The transcriptional reprogramming of key genes involved in hormone biosynthesis at an early stage of infection on Mp717 suggests a metabolic adaptation that ultimately results in resistance against $F$. graminearum. After pathogen infection, SA boosts host cell death to hamper pathogen proliferation by generation of ROS, increasing expression of defense-related genes and establishing a long-term and broad-spectrum resistance on all plant tissues called systemic acquired resistance (Dempsey et al. 1999; Fu and Dong 2013). These changes are accompanied by repression of key genes on the jasmonate pathway such as allene oxide cyclase (Leon-Reyes et al. 2010) and auxinresponsive genes (Mauch-Mani and Mauch 2005). The repression of auxin-responsive genes by SA may be key for Mp717 resistance because auxin promotes susceptibility to hemibiotroph pathogens (Mauch-Mani and Mauch 2005; Wang et al. 2007). Moreover, SA mutants lose transcriptional reprogramming faculties and become susceptible to (hemi)-biotrophic pathogens (Dong 2004), including $F$. oxysporum (Di et al. 2016; Michielse and Rep 2009) and $F$. graminearum on wheat (Makandar et al. 2006). However, SA accumulation has a negative impact on growth and reproduction, and it is strongly regulated to balance immunity and fitness (Chandran et al. 2014). This regulation can be done by ABA which tailors regulatory functions under single and combined stresses (Suzuki 2016), antagonizing SA-mediated defense (Mohr and Cahill 2007; Yasuda et al. 2008) by modulating defense response, cell wall metabolism, and ROS production (Bari and Jones 2009; Hernández-Blanco et al. 2007).

Overall, the resistance observed on Mp717 is the product of a coordinated and ordered modulation of the expression of genes involved in ROS accumulation, host defense response, synthesis of defense metabolites, and cell wall remodeling under the action of SA and regulated by other hormones such as ABA. Similar behavior has been observed in other hemibiotrophs during biotrophic to necrotrophic transition such as Leptosphaeria maculans (Haddadi et al. 2016), Macrophomina phaseolina (Chowdhury et al. 2017), and F. graminearum infecting Arabidopsis (Makandar et al. 2010), wheat (Ding et al. 2011), and barley (Geddes et al. 2008), where this transition is frequently delayed on resistant genotypes. The B73 line would be unable to perform this fine tuning adjustment, activating an inappropriate defense response. In addition, oxidative stress is directly related to accumulation of mycotoxins such as DON (Waśkiewicz et al. 2014). DON production can act as positive feedback, increasing ROS levels; hence, DON production by $F$. graminearum may interfere with the defense response directing the plant toward an oxidative burst (Audenaert et al. 2013). Nonetheless, it is important to highlight the fact that the constitutive activation of SA, expression of defense response, or imbalance on hormonal abundance could result in detrimental phenotypes on maize and other crops (Collinge et al. 2010; López et al. 2008). In fact, most of the mycotoxin-resistant inbred lines such as Mp717 have undesirable traits such as low yield due to its genetic background and polygenic nature of resistance (Prasad et al. 2019), making it difficult to transfer resistance to adapted germplasm using conventional breeding methods.

\section{Mp717 displays overexpression of cytoskeleton activity and cell wall remodeling during early stages of $F$. graminearum infection}

Comparison IV (B73-PH1 versus Mp717-PH1) provided insights on key genes associated with resistance to stalk rot on Mp717. During the first 2 weeks of $F$. graminearum infection, Mp717 compared with B73 displayed an increase of transcriptional activity in genes associated with cell wall remodeling, cytoskeleton mobility, and defense proteins in conjunction with significant reduction of multiple metabolic functions, mainly genes associated with oxido-reduction processes. This modulation on Mp717 suggests a reprogramming of cellular processes for an effective defense response (Buscaill and Rivas 
2014), potentially mediating the trade-off between growth and immunity (Fan et al. 2014; Huot et al. 2014). Energy saved during downregulation of metabolic processes coupled with upregulation of photosynthesis-related genes increases energy (Göhre et al. 2012; Liu et al. 2013), which may be used to upregulate key defense genes (Rojas et al. 2014) or production of defense response raw materials (Huot et al. 2014; Swarbrick et al. 2006), or to increase $F$. graminearum tolerance by filling pathogen carbon demand (Berger et al. 2007).

The plant cell wall is a physical barrier against pathogen invasion composed of a complex network of polysaccharidescelluloses, hemicelluloses, pectins, and glycoproteins (Delaunois et al. 2014) - and antimicrobial compounds (Hardham et al. 2007). Reinforced by lignins, waxes, or cutins (Carpita and Gibeaut 1993), it also provides an environment for the immune response and intercellular communication (Sakurai 1998). F. graminearum penetrates and colonizes host tissue using an arsenal of cell-walldegrading enzymes (Yang et al. 2012); hence, the composition and content of cell wall polymers influence host susceptibility (Bacete et al. 2018; Blümke et al. 2015; Lahlali et al. 2016). Mp717 showed differential upregulation of several genes related to cell wall metabolism during the first 2 weeks of $F$. graminearum infection (Fig. 5; Supplementary File S3). Such genes included 3-ketoacyl-CoA synthase involved in biosynthesis of cuticular wax (Domínguez et al. 2011), and several glucosidases and pectin esterases associated with the production of intermediaries for cell wall lignification (Dharmawardhana et al. 1995; Wang et al. 2013), phytohormone activation (Lee et al. 2006), and cell wall remodeling and strengthening (Blümke et al. 2015; Lionetti et al. 2012; McMillan et al. 1993; Wydra and Beri 2006). The overexpression of microtubular kinases may also be related to the organization and maintenance of cell wall structure (Bashline et al. 2014; Brandizzi and Wasteneys 2013). It has been reported that microtubular networks ensure the proper distribution of cellulose synthases (Lei et al. 2012) on cell walls and also establish a connection with plasma membrane and immune receptors responsible for signal transduction of the plant immune response (Brandizzi and Wasteneys 2013; Day et al. 2011; Nebenführ and Dixit 2018), cellular trafficking of metabolites and organelles to the site of infection, and regulation of transcription (Brandizzi and Wasteneys 2013; Takemoto et al. 2003).

\section{Environmental conditions influence disease severity, fungal biomass accumulation, and the resistance response to stalk rot}

Our study confirmed the previously reported contrasting response to stalk rot between B73 and Mp717 (Quesada-Ocampo et al. 2016) and expanded those findings by estimating the $F$. graminearum biomass by qRT-PCR during the infection and colonization phases (Stephens et al. 2008). These phases involved hyphal development, intracellular growth, and early penetration of parenchyma cells ( $2 \mathrm{dpi}$ ), followed by mycelial growth from the inoculation point to the pit cavity (14 dpi), and extensive colonization of the internal tissue (28 dpi) (Guenther and Trail 2005; Stephens et al. 2008; Zhang et al. 2016).

Stalk rot disease ratings and fungal GAPDH expression revealed that disease severity and fungal biomass are influenced by environmental conditions, with the growth chamber showing higher values than the greenhouse conditions. The growth chamber had higher humidity $(>60 \%)$ and temperature $\left(>35^{\circ} \mathrm{C}\right)$, which are more conducive for $F$. graminearum proliferation and development (Manstretta and Rossi 2016).
Significant differences were also observed in qRT-PCR gene expression profiles between the inbred lines in the two environments (Fig. 6). Our findings of the environment influencing disease response at the gene expression level could explain the variability in stalk rot losses in inbred lines due to environmental differences during the growing season, particularly under high moisture $(>60 \%)$ and temperatures $\left(18\right.$ to $\left.29^{\circ} \mathrm{C}\right)$ (Koehler 1960; Sutton 1982).

Six genes induced by hormones such as SA and ABA and associated with Fusarium resistance QTLs (Herrera-Vasquez et al. 2015; Vlot et al. 2009) displayed a characteristic expression pattern on Mp717 under greenhouse conditions. These genes included cytochrome P450 family 72 (CYP72A15) (Zm00001d044147),

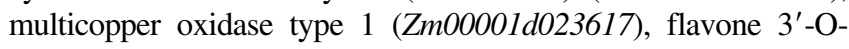
methyltransferase 1 (Zm00001d048087), pathogenesis-related protein 7 (Zm00001d028815), peroxidase 12 (Zm00001d042022), and pathogenesis-related protein 10 (Zm00001d028816), and showed significant downregulation at 14 dpi followed by a significant increase of gene expression at 28 dpi compared with B73. In wheat, cytochrome P450 monooxygenases type 72 (CYP72A) is induced as part of an early response to mycotoxin biosynthesis and some variants contribute to DON resistance (Gunupuru et al. 2018). Multicopper oxidases (Janusz et al. 2020), flavone 3'-O-methyltransferase 1 (Kodama et al. 1992), peroxidases (Bindschedler et al. 2006), and pathogenesis-related proteins (PRs) (Edreva 2005) are involved in general disease responses. We evaluated the response of three types of PRs: PR3 (chitinase 2) and the ribonucleaselike PRs, PR7 and PR10. PR10s are organ-dependent genes and their upregulation can be induced by ROS, SA, and biotic stresses (Xie et al. 2010). They have been associated with a QTL region on maize chromosome 1 (Kebede et al. 2018), and used to increase the resistance against $F$. graminearum in wheat by transgenesis (Makandar et al. 2006).

In contrast, the UDP-glucosyltransferase (Zm00001d006140), phenylalanine ammonia lyase 3 (Zm00001d051161) ET-responsive transcription factor 15 (Zm00001d019475), and chitinase 2 (Zm00001d036370) were similarly upregulated at 2 dpi under growth room conditions for both inbred lines. The UDPglucosyltransferase plays a key role in the interaction with Fusarium spp. by deactivating DON (He et al. 2018; Li et al. 2017) and ROS scavenging (Lim et al. 2008). The enzyme phenylalanine ammonia lyase catalyzes deamination of phenylalanine, a central intermediary from the primary to secondary metabolism in plants (Hahlbrock and Scheel 1989), being triggered for different stresses (Dixon and Paiva 1995). The ET-responsive factor 15 can be induced by different hormones and oxidative stresses, suggesting that they can regulate ROS-responsive gene expression (Lorenzo et al. 2003; Müller and Munné-Bosch 2015). Chitinase 2 activity enhances immunity against $F$. graminearum (Dowd et al. 2018).

In summary, a coordinated modulation of gene expression seems to be crucial to halt $F$. graminearum infection in Mp717 stalks. The modulation of gene expression as a strategy to reduce the disease severity observed in Mp717 seems to contrast with that observed in similar time-course RNA-seq experiments with $F$. graminearum in stalks (Liu et al. 2016) and ears (Yuan et al. 2020) from other genotypes, where a strong defense response was observed at early stages on the resistant genotypes.

Most fungal plant diseases that affect aerial tissues are favored by high humidity and temperature conditions. At high temperatures, more water vapor and dew facilitate pathogen infection because plant resistance pathways are also affected (Cheng et al. 2013; Ferrocino et al. 2013; Melloy et al. 2014; Velásquez et al. 2018). In addition, Fusarium spp. activate 
secondary metabolism, which is affected by humidity and temperature, to overcome host defenses by increasing mycotoxin production (Beyer et al. 2005; Logrieco et al. 2007; Magan et al. 2010; Ponts 2015; Stephens et al. 2008). Under field conditions, both plants and pathogens are subject to multiple environmental factors that determine the disease outcome; therefore, the use of artificial simulation of climatic scenarios to study plant-Fusarium interactions will be critical when characterizing these pathosystems because climate change could increase the incidence of Fusarium-related plant diseases (Cairns et al. 2012; Ferrocino et al. 2013).

Our transcriptomic study provides valuable resources to understand the molecular mechanisms and environmental factors underlying the resistance to stalk rot and low mycotoxin accumulation in maize. These resources would be exploited to accelerate maize breeding by identifying markers linked to candidate genes or alleles and QTLs (Robertson et al. 2005). Our transcriptome analysis has applications in identifying metabolic pathways, preferentially expressed genes, and regulatory mechanisms responsible for stalk rot resistance. Experimental validation of pathways and metabolic networks predicted by our transcriptome analysis would determine the role of key genes in different genotypes and similar pathosystems involving mycotoxin-producing fungi. Identification of appropriate genes or pathways is critical in targeted breeding strategies and genetic engineering focused on obtaining an adequate defense response against stalk rot without yield penalties in existing varieties or developing superior resistance varieties.

\section{ACKNOWLEDGMENTS}

We thank all the members of the Quesada lab for their valuable help; and G. Brown, E. Crisovan, B. Vaillancourt, M., M. Hardin, A. Boone, J. Dominguez-Díaz, A. Quiroz-Moreno, and J. Standish for their technical assistance.

\section{LITERATURE CITED}

Acosta, I. F., Laparra, H., Romero, S. P., Schmelz, E., Hamberg, M., Mottinger, J. P., Moreno, M. A., and Dellaporta, S. L. 2009. Tasselseed1 is a lipoxygenase affecting jasmonic acid signaling in sex determination of maize. Science 323:262-265.

Alfano, G., Ivey, M. L. L., Cakir, C., Bos, J. I. B., Miller, S. A., Madden, L. V., Kamoun, S., and Hoitink, H. A. J. 2007. Systemic modulation of gene expression in tomato by Trichoderma hamatum 382. Phytopathology 97:429-437.

Ali, M. L., Taylor, J. H., Jie, L., Sun, G., William, M., Kasha, K. J., Reid, L. M., and Pauls, K. P. 2005. Molecular mapping of QTLs for resistance to Gibberella ear rot, in corn, caused by Fusarium graminearum. Genome 48:521-533.

Ali, S., Ganai, B. A., Kamili, A. N., Bhat, A. A., Mir, Z. A., Bhat, J. A., Tyagi, A., Islam, S. T., Mushtaq, M., Yadav, P., Rawat, S., and Grover, A. 2018. Pathogenesis-related proteins and peptides as promising tools for engineering plants with multiple stress tolerance. Microbiol. Res. 212-213:29-37.

Andersen, C. L., Jensen, J. L., and Ørntoft, T. F. 2004. Normalization of real-time quantitative reverse transcription-PCR data: A model-based variance estimation approach to identify genes suited for normalization, applied to bladder and colon cancer data sets. Cancer Res. 64:5245-5250.

Andrews, S. 2010. FASTQC. A quality control tool for high throughput sequence data. https://www.bioinformatics.babraham.ac.uk/projects/ fastqc/

Ashburner, M., Ball, C. A., Blake, J. A., Botstein, D., Butler, H., and Cherry, J. M. 2000. Gene Ontology: Tool for the unification of biology. Nat. Genet. 25:25-29.
Audenaert, K., Vanheule, A., Höfte, M., and Haesaert, G. 2013. Deoxynivalenol: A major player in the multifaceted response of Fusarium to its environment. Toxins (Basel) 6:1-19.

Bacete, L., Mélida, H., Miedes, E., and Molina, A. 2018. Plant cell wallmediated immunity: Cell wall changes trigger disease resistance responses. Plant J. 93:614-636.

Balakireva, A., and Zamyatnin, A. 2018. Indispensable role of proteases in plant innate immunity. Int. J. Mol. Sci. 19:629.

Banasiak, J., Biała, W., Staszków, A., Swarcewicz, B., Kepczyńska, E., Figlerowicz, M., and Jasiński, M. 2013. A Medicago truncatula ABC transporter belonging to subfamily $G$ modulates the level of isoflavonoids. J. Exp. Bot. 64:1005-1015.

Bari, R., and Jones, J. D. G. 2009. Role of plant hormones in plant defence responses. Plant Mol. Biol. 69:473-488.

Bashline, L., Lei, L., Li, S., and Gu, Y. 2014. Cell wall, cytoskeleton, and cell expansion in higher plants. Mol. Plant 7:586-600.

Beccari, G., Arellano, C., Covarelli, L., Tini, F., Sulyok, M., and Cowger, C. 2019. Effect of wheat infection timing on Fusarium head blight causal agents and secondary metabolites in grain. Int. J. Food Microbiol. 290: 214-225.

Berger, S., Sinha, A. K., and Roitsch, T. 2007. Plant physiology meets phytopathology: Plant primary metabolism and plant pathogen interactions. J. Exp. Bot. 58:4019-4026.

Bernardo, A., Bai, G., Guo, P., Xiao, K., Guenzi, A. C., and Ayoubi, P. 2006. Fusarium graminearum-induced changes in gene expression between Fusarium head blight-resistant and susceptible wheat cultivars. Funct. Integr. Genomics 7:69-77.

Beyer, M., Verreet, J.-A., and Ragab, W. S. M. 2005. Effect of relative humidity on germination of ascospores and macroconidia of Gibberella zeae and deoxynivalenol production. Int. J. Food Microbiol. 98:233-240.

Bindschedler, L. V., Dewdney, J., Blee, K. A., Stone, J. M., Asai, T., Plotnikov, J., Denoux, C., Hayes, T., Gerrish, C., Davies, D. R., Ausubel, F. M., and Bolwell, G. P. 2006. Peroxidase-dependent apoplastic oxidative burst in Arabidopsis required for pathogen resistance. Plant J. 47:851-863.

Blümke, A., Sode, B., Ellinger, D., and Voigt, C. A. 2015. Reduced susceptibility to Fusarium head blight in Brachypodium distachyon through priming with the Fusarium mycotoxin deoxynivalenol. Mol. Plant Pathol. 16:472-483.

Boedi, S., Berger, H., Sieber, C., Münsterkötter, M., Maloku, I., Warth, B., Sulyok, M., Lemmens, M., Schuhmacher, R., Güldener, U., and Strauss, J. 2016. Comparison of Fusarium graminearum transcriptomes on living or dead wheat differentiates substrate-responsive and defense-responsive genes. Front. Microbiol. 7:1113.

Boller, T., and Felix, G. 2009. A Renaissance of elicitors: Perception of microbe-associated molecular patterns and danger signals by patternrecognition receptors. Annu. Rev. Plant Biol. 60:379-406.

Bontpart, T., Cheynier, V., Ageorges, A., and Terrier, N. 2015. BAHD or SCPL acyltransferase? What a dilemma for acylation in the world of plant phenolic compounds. New Phytol. 208:695-707.

Brandizzi, F., and Wasteneys, G. O. 2013. Cytoskeleton-dependent endomembrane organization in plant cells: An emerging role for microtubules. Plant J. 75:339-349.

Buscaill, P., and Rivas, S. 2014. Transcriptional control of plant defense responses. Curr. Opin. Plant Biol. 20:35-46.

Butrón, A., Reid, L. M., Santiago, R., Cao, A., and Malvar, R. A. 2015. Inheritance of maize resistance to Gibberella and Fusarium ear rots and kernel contamination with deoxynivalenol and fumonisins. Plant Pathol. 64:1053-1060.

Cairns, J. E., Sonder, K., Zaidi, P. H., Verhulst, N., Mahuku, G., and Babu, R. 2012. Maize production in a changing climate: Impacts, adaptation, and mitigation strategies. Adv. Agron. 114:1-58.

Carpita, N. C., and Gibeaut, D. M. 1993. Structural models of primary cell walls in flowering plants: Consistency of molecular structure with the physical properties of the walls during growth. Plant J. 3:1-30.

Chandran, D., Rickert, J., Huang, Y., Steinwand, M. A., Marr, S. K., and Wildermuth, M. C. 2014. Atypical E2F transcriptional repressor DEL1 acts at the intersection of plant growth and immunity by controlling the hormone salicylic acid. Cell Host Microbe 15:506-513.

Chaouch, S., Queval, G., and Noctor, G. 2012. AtRbohF is a crucial modulator of defence-associated metabolism and a key actor in the 
interplay between intracellular oxidative stress and pathogenesis responses in Arabidopsis. Plant J. 69:613-627.

Chen, Q., Song, J., Du, W.-P., Xu, L.-Y., Jiang, Y., Zhang, J., Xiang, X.-L., and Yu, G.-R. 2017. Identification, mapping, and molecular marker development for Rgsr8.1: A new quantitative trait locus conferring resistance to Gibberella stalk rot in maize Zea mays L. Front. Plant Sci. $8: 1355$.

Cheng, C., Gao, X., Feng, B., Sheen, J., Shan, L., and He, P. 2013. Plant immune response to pathogens differs with changing temperatures. Nat. Commun. 4:2530.

Choudhury, F. K., Rivero, R. M., Blumwald, E., and Mittler, R. 2017. Reactive oxygen species, abiotic stress and stress combination. Plant J. 90:856-867.

Chowdhury, S., Basu, A., and Kundu, S. 2017. Biotrophy-necrotrophy switch in pathogen evoke differential response in resistant and susceptible sesame involving multiple signaling pathways at different phases. Sci. Rep. 7:17251.

Collinge, D. B., Jørgensen, H. J. L., Lund, O. S., and Lyngkjær, M. F. 2010. Engineering pathogen resistance in crop plants: Current trends and future prospects. Annu. Rev. Phytopathol. 48:269-291.

Cuomo, C. A., Guldener, U., Xu, J.-R., Trail, F., and Turgeon, B. G. 2007. The Fusarium graminearum genome reveals a link between localized polymorphism and pathogen specialization. Science 317:1400-1402.

Day, B., Henty, J. L., Porter, K. J., and Staiger, C. J. 2011. The pathogenactin connection: A platform for defense signaling in plants. Annu. Rev. Phytopathol. 49:483-506.

Delaunois, B., Jeandet, P., Clément, C., Baillieul, F., Dorey, S., and Cordelier, S. 2014. Uncovering plant-pathogen crosstalk through apoplastic proteomic studies. Front. Plant Sci. 5:249.

De León, C., and Pandey, S. 1989. Improvement of resistance to ear and stalk rots and agronomic traits in tropical maize gene pools. Crop Sci. 29:12-17.

Dempsey, D. A., Shah, J., and Klessig, D. F. 1999. Salicylic acid and disease resistance in plants. Crit. Rev. Plant Sci. 18:547-575.

Dharmawardhana, D. P., Ellis, B. E., and Carlson, J. E. 1995. A [beta]glucosidase from lodgepole pine xylem specific for the lignin precursor coniferin. Plant Physiol. 107:331-339.

Di, X., Takken, F. L. W., and Tintor, N. 2016. How phytohormones shape interactions between plants and the soil-borne fungus Fusarium oxysporum. Front. Plant Sci. 7:170.

Ding, L., Xu, H., Yi, H., Yang, L., Kong, Z., Zhang, L., Xue, S., Jia, H., and $\mathrm{Ma}, \mathrm{Z}$. 2011. Resistance to hemi-biotrophic $F$. graminearum infection is associated with coordinated and ordered expression of diverse defense signaling pathways. PLoS One 6:e19008.

Dixon, R. A., and Paiva, N. L. 1995. Stress-induced phenylpropanoid metabolism. Plant Cell 7:1085-1097.

Dmitriev, A. A., Krasnov, G. S., Rozhmina, T. A., Novakovskiy, R. O., Snezhkina, A. V., Fedorova, M. S., Yurkevich, O. Y., Muravenko, O. V., Bolsheva, N. L., Kudryavtseva, A. V., and Melnikova, N. V. 2017. Differential gene expression in response to Fusarium oxysporum infection in resistant and susceptible genotypes of flax Linum usitatissimum L. BMC Plant Biol. 17:253.

Domínguez, E., Heredia-Guerrero, J. A., and Heredia, A. 2011. The biophysical design of plant cuticles: An overview. New Phytol. 189: 938-949.

Dong, X. 2004. NPR1, all things considered. Curr. Opin. Plant Biol. 7:547552.

Dowd, P. F., Naumann, T. A., Price, N. P. J., and Johnson, E. T. 2018. Identification of a maize Zea mays chitinase allele sequence suitable for a role in ear rot fungal resistance. Agri Gene 7:15-22.

Edreva, A. 2005. Pathogenesis-related proteins: Research progress in the last 15 years. Gen. Appl. Plant Physiol. 31:105-124.

Fan, M., Bai, M.-Y., Kim, J.-G., Wang, T., Oh, E., Chen, L., Park, C. H., Son, S.-H., Kim, S.-K., Mudgett, M. B., and Wang, Z.-Y. 2014. The bHLH transcription factor HBI1 mediates the trade-off between growth and pathogen-associated molecular pattern-triggered immunity in Arabidopsis. Plant Cell 26:828-841.

FAO. 2018. The State of Food Security and Nutrition in the World 2018. Building Climate Resilience for Food Security and Nutrition. FAO, Rome, Italy.
FAO. 2020. Crop Prospects and Food Situation-Quarterly Global Report No. 2, July 2020. FAO, Rome, Italy.

Ferrocino, I., Chitarra, W., Pugliese, M., Gilardi, G., Gullino, M. L., and Garibaldi, A. 2013. Effect of elevated atmospheric $\mathrm{CO}_{2}$ and temperature on disease severity of Fusarium oxysporum f. sp. lactucae on lettuce plants. Appl. Soil Ecol. 72:1-6.

Figueiredo, A., Monteiro, F., and Sebastiana, M. 2014. Subtilisin-like proteases in plant-pathogen recognition and immune priming: A perspective. Front. Plant Sci. 5:739.

Freije, A., Wise, K. A., and Nielsen, B. 2016. Diseases of corn: Stalk rots. Purdue University Ext. BP-89W.

Fu, Z. Q., and Dong, X. 2013. Systemic acquired resistance: Turning local infection into global defense. Annu. Rev. Plant Biol. 64:839-863.

Gaffoor, I., Brown, D. W., Plattner, R., Proctor, R. H., Qi, W., and Trail, F. 2005. Functional analysis of the polyketide synthase genes in the filamentous Fungus Gibberella zeae Anamorph Fusarium graminearum. Eukaryot. Cell 4:1926-1933.

Geddes, J., Eudes, F., Laroche, A., and Selinger, L. B. 2008. Differential expression of proteins in response to the interaction between the pathogen Fusarium graminearum and its host, Hordeum vulgare. Proteomics 8:545-554.

Gilbertson, R. L., Brown, W. M., and Ruppel, E. G. 1985. Prevalence and virulence of Fusarium spp. associated with stalk rot of corn in Colorado. Plant Dis. 69:1065-1068.

Gilroy, S., Białasek, M., Suzuki, N., Górecka, M., Devireddy, A. R., Karpiński, S., and Mittler, R. 2016. ROS, Calcium, and electric signals: Key mediators of rapid systemic signaling in plants. Plant Physiol. 171: 1606-1615.

Gindro, K., Berger, V., Godard, S., Voinesco, F., Schnee, S., Viret, O., and Alonso-Villaverde, V. 2012. Protease inhibitors decrease the resistance of Vitaceae to Plasmopara viticola. Plant Physiol. Biochem. 60:74-80.

Göhre, V., Jones, A. M. E., Sklenáŕ, J., Robatzek, S., and Weber, A. P. M. 2012. Molecular crosstalk between PAMP-triggered immunity and photosynthesis. Mol. Plant-Microbe Interact. 25:1083-1092.

Goswami, R. S., and Kistler, H. C. 2004. Heading for disaster: Fusarium graminearum on cereal crops. Mol. Plant Pathol. 5:515-525.

Guenther, J. C., and Trail, F. 2005. The development and differentiation of Gibberella zeae (anamorph: Fusarium graminearum) during colonization of wheat. Mycologia 97:229-237.

Gunupuru, L. R., Arunachalam, C., Malla, K. B., Kahla, A., Perochon, A., Jia, J., Thapa, G., and Doohan, F. M. 2018. A wheat cytochrome P450 enhances both resistance to deoxynivalenol and grain yield. PLoS One 13:e0204992.

Haddadi, P., Ma, L., Wang, H., and Borhan, M. H. 2016. Genome-wide transcriptomic analyses provide insights into the lifestyle transition and effector repertoire of Leptosphaeria maculans during the colonization of Brassica napus seedlings. Mol. Plant Pathol. 17:1196-1210.

Hahlbrock, K., and Scheel, D. 1989. Physiology and molecular biology of phenylpropanoid metabolism. Annu. Rev. Plant Physiol. Plant Mol. Biol. 40:347-369.

Hardham, A. R., Jones, D. A., and Takemoto, D. 2007. Cytoskeleton and cell wall function in penetration resistance. Curr. Opin. Plant Biol. 10:342348.

Harris, L. J., Balcerzak, M., Johnston, A., Schneiderman, D., and Ouellet, T. 2016. Host-preferential Fusarium graminearum gene expression during infection of wheat, barley, and maize. Fungal Biol. 120:111-123.

He, Y., Ahmad, D., Zhang, X., Zhang, Y., Wu, L., Jiang, P., and Ma, H. 2018. Genome-wide analysis of family-1 UDP glycosyltransferases UGT and identification of UGT genes for FHB resistance in wheat Triticum aestivum L. BMC Plant Biol. 18:67.

Henry, W. B., Williams, W. P., Windham, G. L., and Hawkins, L. K. 2009. Evaluation of maize inbred lines for resistance to Aspergillus and Fusarium ear rot and mycotoxin accumulation. Agron. J. 101:1219-1226. Hernández-Blanco, C., Feng, D. X., Hu, J., Sánchez-Vallet, A., Deslandes, L., Llorente, F., Berrocal-Lobo, M., Keller, H., Barlet, X., SánchezRodríguez, C., Anderson, L. K., Somerville, S., Marco, Y., and Molina, A. 2007. Impairment of cellulose synthases required for Arabidopsis secondary cell wall formation enhances disease resistance. Plant Cell 19:890-903. 
Herrera-Vasquez, A., Salinas, P., and Holuigue, L. 2015. Salicylic acid and reactive oxygen species interplay in the transcriptional control of defense genes expression. Front. Plant Sci. 6:171.

Huot, B., Yao, J., Montgomery, B. L., and He, S. Y. 2014. Growth-defense tradeoffs in plants: A balancing act to optimize fitness. Mol. Plant 7:12671287.

Janusz, G., Pawlik, A., Świderska-Burek, U., Polak, J., Sulej, J., JaroszWilkołazka, A., and Paszczyński, A. 2020. Laccase properties, physiological functions, and evolution. Int. J. Mol. Sci. 21:966.

Javed, S., Ahmad, M., Ahmad, M., Abdin, M., Hamid, R., Khan, M., and Musarrat, J. 2013. Chitinases: An update. J. Pharm. Bioallied Sci. 5:21.

Jiao, Y., Peluso, P., Shi, J., Liang, T., Stitzer, M. C., and Wang, B. 2017. Improved maize reference genome with single-molecule technologies. Nature 546:524-527.

Jordá, L., and Vera, P. 2000. Local and systemic induction of two defenserelated subtilisin-like protease promoters in transgenic Arabidopsis plants. luciferin induction of $P R$ gene expression. Plant Physiol. 124: 1049-1058.

Kärkönen, A., and Kuchitsu, K. 2015. Reactive oxygen species in cell wall metabolism and development in plants. Phytochemistry 112:22-32.

Kaschani, F., Gu, C., Niessen, S., Hoover, H., Cravatt, B. F., and van der Hoorn, R. A. L. 2009. Diversity of serine hydrolase activities of unchallenged and Botrytis-infected Arabidopsis thaliana. Mol. Cell. Proteomics 8:1082-1093.

Kazan, K., and Gardiner, D. M. 2018. Transcriptomics of cereal-Fusarium graminearum interactions: What we have learned so far. Mol. Plant Pathol. 19:764-778.

Kazan, K., Gardiner, D. M., and Manners, J. M. 2012. On the trail of a cereal killer: Recent advances in Fusarium graminearum pathogenomics and host resistance. Mol. Plant Pathol. 13:399-413.

Kebede, A. Z., Johnston, A., Schneiderman, D., Bosnich, W., and Harris, L. J. 2018. Transcriptome profiling of two maize inbreds with distinct responses to Gibberella ear rot disease to identify candidate resistance genes. BMC Genomics 19:131.

Kim, D., Pertea, G., Trapnell, C., Pimentel, H., Kelley, R., and Salzberg, S. L. 2013. TopHat2: Accurate alignment of transcriptomes in the presence of insertions, deletions and gene fusions. Genome Biol. 14:R36.

Kodama, O., Miyakawa, J., Akatsuka, T., and Kiyosawa, S. 1992. Sakuranetin, a flavanone phytoalexin from ultraviolet-irradiated rice leaves. Phytochemistry 31:3807-3809.

Koehler, B. 1960. Corn stalk rots in Illinois. Univ. Ill. Agric. Exp. Stn.

Krochko, J. E., Abrams, G. D., Loewen, M. K., Abrams, S. R., and Cutler, A. J. 1998. (+)-Abscisic acid 8' -hydroxylase is a cytochrome $\mathrm{P} 450$ monooxygenase. Plant Physiol. 118:849-860.

Lahlali, R., Kumar, S., Wang, L., Forseille, L., Sylvain, N., Korbas, M., Muir, D., and Swerhone, G. 2016. Cell wall biomolecular composition plays a potential role in the host type II resistance to Fusarium head blight in wheat. Front. Microbiol. 7:910.

Lal, S., and Singh, I. S. 1984. Breeding for resistance to downy mildews and stalk rots in maize. Theor. Appl. Genet. 69:111-119.

Lanubile, A., Maschietto, V., Borrelli, V. M., Stagnati, L., Logrieco, A. F., and Marocco, A. 2017. Molecular basis of resistance to Fusarium ear rot in maize. Front. Plant Sci. 8:1774.

Lee, K. H., Piao, H. L., Kim, H.-Y., Choi, S. M., Jiang, F., Hartung, W., Hwang, I., Kwak, J. M., Lee, I.-J., and Hwang, I. 2006. Activation of glucosidase via stress-induced polymerization rapidly increases active pools of abscisic acid. Cell 126:1109-1120.

Lei, L., Li, S., and Gu, Y. 2012. Cellulose synthase complexes: Composition and regulation. Front. Plant Sci. 3:75.

Leon-Reyes, A., Van der Does, D., De Lange, E. S., Delker, C., Wasternack, C., Van Wees, S. C. M., Ritsema, T., and Pieterse, C. M. J. 2010. Salicylate-mediated suppression of jasmonate-responsive gene expression in Arabidopsis is targeted downstream of the jasmonate biosynthesis pathway. Planta 232:1423-1432.

Lewis, L. A., Polanski, K., de Torres-Zabala, M., Jayaraman, S., Bowden, L., and Moore, J. 2015. Transcriptional dynamics driving MAMPtriggered immunity and pathogen effector-mediated immunosuppression in Arabidopsis leaves following infection with Pseudomonas syringae pv tomato DC3000. Plant Cell 27:3038-3064.
Li, W., He, P., and Jin, J. 2010. Effect of Potassium on ultrastructure of maize stalk pith and young root and their relation to stalk rot resistance. Agric. Sci. China 9:1467-1474.

Li, X., Michlmayr, H., Schweiger, W., Malachova, A., Shin, S., Huang, Y., Dong, Y., Wiesenberger, G., McCormick, S., Lemmens, M., Fruhmann, P., Hametner, C., Berthiller, F., Adam, G., and Muehlbauer, G. J. 2017. A barley UDP-glucosyltransferase inactivates nivalenol and provides Fusarium Head Blight resistance in transgenic wheat. J. Exp. Bot. 68: 2187-2197.

Lim, C., Choi, J., Kim, I., Lee, S., Hwang, Y., Lee, C., and Lim, J. 2008. Improved resistance to oxidative stress by a loss-of-function mutation in the Arabidopsis UGT71C1 gene. Mol. Cells 25:368-375.

Lin, W., Ma, X., Shan, L., and He, P. 2013. Big roles of small kinases: The complex functions of receptor-like cytoplasmic kinases in plant immunity and development: Multiple functions of RLCKs. J. Integr. Plant Biol. 55: 1188-1197.

Lionetti, V., Cervone, F., and Bellincampi, D. 2012. Methyl esterification of pectin plays a role during plant-pathogen interactions and affects plant resistance to diseases. J. Plant Physiol. 169:1623-1630.

Liu, R., Xu, Y.-H., Jiang, S.-C., Lu, K., Lu, Y.-F., Feng, X.-J., Wu, Z., Liang, S., Yu, Y.-T., Wang, X.-F., and Zhang, D.-P. 2013. Lightharvesting chlorophyll a/b-binding proteins, positively involved in abscisic acid signalling, require a transcription repressor, WRKY40, to balance their function. J. Exp. Bot. 64:5443-5456.

Liu, Y., Guo, Y., Ma, C., Zhang, D., Wang, C., and Yang, Q. 2016. Transcriptome analysis of maize resistance to Fusarium graminearum. BMC Genomics 17:477.

Livak, K. J., and Schmittgen, T. D. 2001. Analysis of relative gene expression data using real-time quantitative PCR and the $2^{-\Delta \Delta C T}$ method. Methods 25:402-408.

Logrieco, A., Moretti, A., Perrone, G., and Mulè, G. 2007. Biodiversity of complexes of mycotoxigenic fungal species associated with Fusarium ear rot of maize and Aspergillus rot of grape. Int. J. Food Microbiol. 119:11-16.

López, M. A., Bannenberg, G., and Castresana, C. 2008. Controlling hormone signaling is a plant and pathogen challenge for growth and survival. Curr. Opin. Plant Biol. 11:420-427.

Lorenzo, O., Piqueras, R., Sánchez-Serrano, J. J., and Solano, R. 2003. ETHYLENE RESPONSE FACTOR 1 integrates signals from ethylene and jasmonate pathways in plant defense. Plant Cell 15:165-178.

Ma, C., Ma, X., Yao, L., Liu, Y., Du, F., Yang, X., and Xu, M. 2017. qRfg3, a novel quantitative resistance locus against Gibberella stalk rot in maize. Theor. Appl. Genet. 130:1723-1734.

Magan, N., Aldred, D., Mylona, K., and Lambert, R. J. W. 2010. Limiting mycotoxins in stored wheat. Food Addit. Contam. Part A. 27:644-650.

Makandar, R., Essig, J. S., Schapaugh, M. A., Trick, H. N., and Shah, J. 2006. Genetically engineered resistance to Fusarium head blight in wheat by expression of Arabidopsis NPR1. Mol. Plant-Microbe Interact. 19:123-129.

Makandar, R., Nalam, V., Chaturvedi, R., Jeannotte, R., Sparks, A. A., and Shah, J. 2010. Involvement of Salicylate and Jasmonate Signaling pathways in Arabidopsis interaction with Fusarium graminearum. Mol. Plant-Microbe Interact. 23:861-870.

Manoli, A., Sturaro, A., Trevisan, S., Quaggiotti, S., and Nonis, A. 2012. Evaluation of candidate reference genes for $\mathrm{qPCR}$ in maize. J. Plant Physiol. 169:807-815.

Manstretta, V., and Rossi, V. 2016. Effects of temperature and moisture on development of Fusarium graminearum perithecia in maize stalk residues. Appl. Environ. Microbiol. 82:184-191.

Martin, M. 2011. Cutadapt removes adapter sequences from highthroughput sequencing reads. EMBnet. J. 17:10.

Mauch-Mani, B., and Mauch, F. 2005. The role of abscisic acid in plant-pathogen interactions. Curr. Opin. Plant Biol. 8:409-414.

McMillan, G. P., Hedley, D., Fyffe, L., and Pérombelon, M. C. M. 1993. Potato resistance to soft-rot erwinias is related to cell wall pectin esterification. Physiol. Mol. Plant Pathol. 42:279-289 d.

Melloy, P., Aitken, E., Luck, J., Chakraborty, S., and Obanor, F. 2014. The influence of increasing temperature and $\mathrm{CO}_{2}$ on Fusarium crown rot susceptibility of wheat genotypes at key growth stages. Eur. J. Plant Pathol. 140:19-37. 
Mi, H., Muruganujan, A., Ebert, D., Huang, X., and Thomas, P. D. 2019. PANTHER version 14: More genomes, a new PANTHER GO-slim and improvements in enrichment analysis tools. Nucleic Acids Res. 47: D419-D426.

Michielse, C. B., and Rep, M. 2009. Pathogen profile update: Fusarium oxysporum. Mol. Plant Pathol. 10:311-324.

Millar, A. A., Jacobsen, J. V., Ross, J. J., Helliwell, C. A., Poole, A. T., Scofield, G., Reid, J. B., and Gubler, F. 2006. Seed dormancy and ABA metabolism in Arabidopsis and barley: The role of ABA 8'-hydroxylase. Plant J. 45:942-954.

Miller, J. D. 1994. Epidemiology of Fusarium ear diseases of cereals. Pages 19-36 in: Mycotoxins in Grain: Compounds Other than Aflatoxin., J. D. Miller and H. L. Trenholn, eds. Eagan Press, St. Paul, MN, U.S.A.

Mohammadi, M., Anoop, V., Gleddie, S., and Harris, L. J. 2011. Proteomic profiling of two maize inbreds during early Gibberella ear rot infection. Proteomics 11:3675-3684.

Mohr, P. G., and Cahill, D. M. 2007. Suppression by ABA of salicylic acid and lignin accumulation and the expression of multiple genes, in Arabidopsis infected with Pseudomonas syringae pv. tomato. Funct. Integr. Genomics 7:181-191.

Mueller, D. S., Wise, K. A., Sisson, A. J., Allen, T. W., Bergstrom, G. C., and Bosley, D. B. 2016. Corn yield loss estimates due to diseases in the United States and Ontario, Canada from 2012 to 2015. Plant Health Prog. 17:211-222.

Mugford, S. T., and Milkowski, C. 2012. Serine carboxypeptidase-like acyltransferases from plants. Methods Enzymol. 516:279-297.

Müller, M., and Munné-Bosch, S. 2015. Ethylene response factors: A key regulatory hub in hormone and stress signaling. Plant Physiol. 169:32-41.

Munkvold, G. P. 2003. Epidemiology of Fusarium diseases and their mycotoxins in maize ears. Eur. J. Plant Pathol. 109:705-713.

Munson, M., and Novick, P. 2006. The exocyst defrocked, a framework of rods revealed. Nat. Struct. Mol. Biol. 13:577-581.

Nebenführ, A., and Dixit, R. 2018. Kinesins and myosins: Molecular motors that coordinate cellular functions in plants. Annu. Rev. Plant Biol. 69: 329-361.

Nuss, E. T., and Tanumihardjo, S. A. 2010. Maize: A paramount staple crop in the context of global nutrition. Compr. Rev. Food Sci. Food Saf. 9:417436.

Osborne, L. E., and Stein, J. M. 2007. Epidemiology of Fusarium head blight on small-grain cereals. Int. J. Food Microbiol. 119:103-108.

Otomo, K., Kenmoku, H., Oikawa, H., König, W. A., Toshima, H., Mitsuhashi, W., Yamane, H., Sassa, T., and Toyomasu, T. 2004. Biological functions of ent - and syn -copalyl diphosphate synthases in rice: Key enzymes for the branch point of gibberellin and phytoalexin biosynthesis. Plant J. 39:886-893.

Parry, D. W., Jenkinson, P., and McLeod, L. 1995. Fusarium ear blight scab in small grain cereals? a review. Plant Pathol. 44:207-238.

Pè, M. E., Gianfranceschi, L., Taramino, G., Tarchini, R., Angelini, P., Dani, M., and Binelli, G. 1993. Mapping quantitative trait loci QTLs for resistance to Gibberella zeae infection in maize. Mol. Gen. Genet. 241: 11-16.

Pfaffl, M. W. 2004. Quantification strategies in real-time PCR. Pages 87112 in: A-Z of Quantitative PCR. S. A. Bustin, ed. International University Line, La Jolla, CA, U.S.A.

Ponts, N. 2015. Mycotoxins are a component of Fusarium graminearum stress-response system. Front. Microbiol. 6:1234.

Prasad, K., Kumar, K. K., and Bhatnagar-Mathur, P. 2019. Biotechnological strategies for development of aflatoxin-free crops. Pages 289-376 in: Nutritional Quality Improvement in Plants. Concepts and Strategies in Plant Sciences. P. Jaiwal, A. Chhillar, D. Chaudhary, and R. Jaiwal, eds. Springer, Cham, Switzerland.

Quesada-Ocampo, L. M., Al-Haddad, J., Scruggs, A. C., Buell, C. R., and Trail, F. 2016. Susceptibility of maize to stalk rot caused by Fusarium graminearum deoxynivalenol and zearalenone mutants. Phytopathology 106:920-927.

Ranum, P., Peña-Rosas, J. P., and Garcia-Casal, M. N. 2014. Global maize production, utilization, and consumption. Ann. N. Y. Acad. Sci. 1312: 105-112.

R Development Core Team. 2010. A Language and Environment for Statistical Computing. R Foundation for Statistical Computing, Vienna, Austria.
Robertson, L. A., Payne, G. A., and Holland, J. B. 2005. Marker assisted breeding for resistance to mycotoxin contamination. Pages 423-443 in: Aflatoxin and Food Safety. H. K. Abbas, ed. Marcel Dekker, Inc., New York, NY, U.S.A.

Rojas, C. M., Senthil-Kumar, M., Tzin, V., and Mysore, K. S. 2014. Regulation of primary plant metabolism during plant-pathogen interactions and its contribution to plant defense. Front. Plant Sci. 5:17.

Rosegrant, M. W., Sulser, T. B., Mason-D'Croz, D., Cenacchi, N., Nin-Pratt, A., Dunston, S., Zhu, T., Ringler, C., Wiebe, K. D., Robinson, S., Willenbockel, D., Xie, H., Kwon, H.-Y., Johnson, T., Thomas, T. S., Wimmer, F., Schaldach, R., Nelson, G. C., and Willaarts, B. 2017. Quantitative foresight modeling to inform the CGIAR research portfolio. Project Report for USAID. International Food Policy Research Institute, Washington, D.C.

Sakurai, N. 1998. Dynamic function and regulation of apoplast in the plant body. J. Plant Res. 111:133-148.

Santiago, R., Reid, L. M., Arnason, J. T., Zhu, X., Martinez, N., and Malvar, R. A. 2007. Phenolics in maize genotypes differing in susceptibility to Gibberella Stalk Rot Fusarium graminearum Schwabe. J. Agric. Food Chem. 55:5186-5193.

Santiago, R., Reid, L. M., Zhu, X., Butrón, A., and Malvar, R. A. 2009. Gibberella stalk rot Fusarium graminearum resistance of maize inbreds and their $F_{1}$ hybrids and their potential for use in resistance breeding programs. Plant Breed. 129:454-456.

Schnable, P. S., Ware, D., Fulton, R. S., Stein, J. C., Wei, F., and Pasternak, S. 2009. The B73 maize genome: Complexity, diversity, and dynamics. Science 326:1112-1115.

Sebastiani, S., Bagnaresi, P., Sestili, S., Biselli, C., Zechini, A., Orrù, L., Cattivelli, L., and Ficcadenti, N. 2017. Transcriptome analysis of the melon-Fusarium oxysporum f. sp. melonis race 1.2 pathosystem in susceptible and resistant plants. Front. Plant Sci. 8:922.

Seo, M., Peeters, A. J. M., Koiwai, H., Oritani, T., Marion-Poll, A., Zeevaart, J. A. D., Koornneef, M., Kamiya, Y., and Koshiba, T. 2000. The Arabidopsis aldehyde oxidase $3 \mathrm{AAO} 3$ gene product catalyzes the final step in abscisic acid biosynthesis in leaves. Proc. Natl. Acad. Sci. U.S.A. 97:12908-12913.

Shiferaw, B., Prasanna, B. M., Hellin, J., and Bänziger, M. 2011. Crops that feed the world 6. past successes and future challenges to the role played by maize in global food security. Food Secur. 3:307-327.

Shin, J., Han, J. H., Lee, J. K., and Kim, K. S. 2014. Characterization of the maize stalk rot pathogens Fusarium subglutinans and $F$. temperatum and the effect of fungicides on their mycelial growth and colony formation. Plant Pathol. J. 30:397-406.

Springer, N. M., Ying, K., Fu, Y., Ji, T., Yeh, C.-T., Jia, Y., Wu, W., Richmond, T., Kitzman, J., Rosenbaum, H., Iniguez, A. L., Barbazuk, W. B., Jeddeloh, J. A., Nettleton, D., and Schnable, P. S. 2009. Maize inbreds exhibit high levels of copy number variation CNV and presence/absence variation PAV in genome content. PLoS Genet. 5: e1000734.

Stephens, A. E., Gardiner, D. M., White, R. G., Munn, A. L., and Manners, J. M. 2008. Phases of infection and gene expression of Fusarium graminearum during crown rot disease of wheat. Mol. Plant-Microbe Interact. 21:1571-1581.

Sutton, J. C. 1982. Epidemiology of wheat head blight and maize ear rot caused by Fusarium graminearum. Can. J. Plant Pathol. 4:195-209.

Suzuki, N. 2016. Hormone signaling pathways under stress combinations. Plant Signal. Behav. 11:e1247139.

Swarbrick, P. J., Schulze-Lefert, P., and Scholes, J. D. 2006. Metabolic consequences of susceptibility and resistance race-specific and broadspectrum in barley leaves challenged with powdery mildew. Plant Cell Environ. 29:1061-1076.

Takemoto, D., Jones, D. A., and Hardham, A. R. 2003. GFP-tagging of cell components reveals the dynamics of subcellular re-organization in response to infection of Arabidopsis by oomycete pathogens. Plant J. 33:775-792.

Taki, N., Sasaki-Sekimoto, Y., Obayashi, T., Kikuta, A., Kobayashi, K., Ainai, T., Yagi, K., Sakurai, N., Suzuki, H., Masuda, T., Takamiya, K., Shibata, D., Kobayashi, Y., and Ohta, H. 2005. 12-oxo-phytodienoic acid triggers expression of a distinct set of genes and plays a role in wound-induced gene expression in Arabidopsis. Plant Physiol. 139: 1268-1283. 
The Gene Ontology Consortium. 2017. Expansion of the Gene Ontology knowledgebase and resources. Nucleic Acids Res. 45:D331-D338.

Tian, T., Liu, Y., Yan, H., You, Q., Yi, X., Du, Z., Xu, W., and Su, Z. 2017. agriGO v2.0: A GO analysis toolkit for the agricultural community, 2017 update. Nucleic Acids Res. 45:W122-W129.

Torres, M. A., and Dangl, J. L. 2005. Functions of the respiratory burst oxidase in biotic interactions, abiotic stress and development. Curr. Opin. Plant Biol. 8:397-403.

Torres, M. A., Jones, J. D. G., and Dangl, J. L. 2006. Reactive oxygen species signaling in response to pathogens. Plant Physiol. 141:373-378.

Trapnell, C., Roberts, A., Goff, L., Pertea, G., Kim, D., Kelley, D. R., Pimentel, H., Salzberg, S. L., Rinn, J. L., and Pachter, L. 2012. Differential gene and transcript expression analysis of RNA-seq experiments with TopHat and Cufflinks. Nat. Protoc. 7:562-578.

Tronchet, M., Balaguã, C., Kroj, T., Jouanin, L., and Roby, D. 2010. Cinnamyl alcohol dehydrogenases-C and $\mathrm{D}$, key enzymes in lignin biosynthesis, play an essential role in disease resistance in Arabidopsis. Mol. Plant Pathol. 11:83-92.

Velásquez, A. C., Castroverde, C. D. M., and He, S. Y. 2018. Plant-pathogen warfare under changing climate conditions. Curr. Biol. 28:R619-R634.

Vlot, A. C., Dempsey, D. A., and Klessig, D. F. 2009. Salicylic acid, a multifaceted hormone to combat disease. Annu. Rev. Phytopathol. 47: 177-206.

Vriezen, W. H., Hulzink, R., Mariani, C., and Voesenek, L. A. C. J. 1999. 1-aminocyclopropane-1-carboxylate oxidase activity limits ethylene biosynthesis in Rumex palustris during submergence. Plant Physiol. 121:189-196.

Wang, C., Li, C., Duan, G., Wang, Y., Zhang, Y., and Yang, J. 2019. Overexpression of Magnaporthe oryzae systemic defense trigger 1 MoSDT1 confers improved rice blast resistance in rice. Int. J. Mol. Sci. 20:4762.

Wang, C., Yang, Q., Wang, W., Li, Y., Guo, Y., Zhang, D., Ma, X., Song, W., Zhao, J., and Xu, M. 2017. A transposon-directed epigenetic change in $\mathrm{ZmCCT}$ underlies quantitative resistance to Gibberella stalk rot in maize. New Phytol. 215:1503-1515.

Wang, D., Pajerowska-Mukhtar, K., Culler, A. H., and Dong, X. 2007. Salicylic acid inhibits pathogen growth in plants through repression of the auxin signaling pathway. Curr. Biol. 17:1784-1790.

Wang, Y., Chantreau, M., Sibout, R., and Hawkins, S. 2013. Plant cell wall lignification and monolignol metabolism. Front. Plant Sci. 4:220.

Warnes, G. R., Bolker, B., Bonebakker, L., Gentleman, R., Huber, W., Liaw, A., Lumley, T., Maechler, M., Magnusson, A., Moeller, S., Schwartz, M., Venables, B., and Galili, T. 2015. gplots: Various R Programming Tools for Plotting Data. R package version 2.16.0. https://cran.r-project.org/ web/packages/gplots/index.html

Waśkiewicz, A., Morkunas, I., Bednarski, W., Mai, V., Formela, M., Beszterda, M., Wiśniewska, H., and Goliński, P. 2014. Deoxynivalenol and oxidative stress indicators in winter wheat inoculated with Fusarium graminearum. Toxins (Basel) 6:575-591.
Williams, W. P., and Windham, G. L. 2006. Registration of maize germplasm line Mp717. Crop Sci. 46:1407-1408.

Wydra, K., and Beri, H. 2006. Structural changes of homogalacturonan, rhamnogalacturonan I and arabinogalactan protein in xylem cell walls of tomato genotypes in reaction to Ralstonia solanacearum. Physiol. Mol. Plant Pathol. 68:41-50.

Xie, Y.-R., Chen, Z.-Y., Brown, R. L., and Bhatnagar, D. 2010. Expression and functional characterization of two pathogenesis-related protein 10 genes from Zea mays. J. Plant Physiol. 167:121-130.

Yang, D. E., Zhang, C. L., Zhang, D. S., Jin, D. M., Weng, M. L., Chen, S. J., Nguyen, H., and Wang, B. 2004. Genetic analysis and molecular mapping of maize Zea mays L. stalk rot resistant gene Rfg1. Theor. Appl. Genet. 108:706-711.

Yang, F., Jensen, J. D., Svensson, B., Jørgensen, H. J. L., Collinge, D. B., and Finnie, C. 2012. Secretomics identifies Fusarium graminearum proteins involved in the interaction with barley and wheat. Mol. Plant Pathol. 13:445-453.

Yang, Q., Yin, G., Guo, Y., Zhang, D., Chen, S., and Xu, M. 2010. A major QTL for resistance to Gibberella stalk rot in maize. Theor. Appl. Genet. 121:673-687.

Yasuda, M., Ishikawa, A., Jikumaru, Y., Seki, M., Umezawa, T., Asami, T., Maruyama-Nakashita, A., Kudo, T., Shinozaki, K., Yoshida, S., and Nakashita, H. 2008. Antagonistic interaction between systemic acquired resistance and the abscisic acid-mediated abiotic stress response in Arabidopsis. Plant Cell 20:1678-1692.

Ye, J., Coulouris, G., Zaretskaya, I., Cutcutache, I., Rozen, S., and Madden, T. L. 2012. Primer-BLAST: A tool to design target-specific primers for polymerase chain reaction. BMC Bioinf. 13:134.

Ye, J., Zhong, T., Zhang, D., Ma, C., Wang, L., Yao, L., Zhang, Q., Zhu, M., and $\mathrm{Xu}, \mathrm{M}$. 2019. The auxin-regulated protein ZmAuxRP1 coordinates the balance between root growth and stalk rot disease resistance in maize. Mol. Plant 12:360-373.

Yuan, G., He, X., Li, H., Xiang, K., Liu, L., Zou, C., Lin, H., Wu, J., Zhang, Z., and Pan, G. 2020. Transcriptomic responses in resistant and susceptible maize infected with Fusarium graminearum. Crop J. 8:153-163.

Zeevaart, J. A. D., and Creelman, R. A. 1988. Metabolism and physiology of abscisic acid. Annu. Rev. Plant Physiol. Plant Mol. Biol. 39:439-473.

Zhang, L., Cenci, A., Rouard, M., Zhang, D., Wang, Y., Tang, W., and Zheng, S.-J. 2019. Transcriptomic analysis of resistant and susceptible banana corms in response to infection by Fusarium oxysporum f. sp. cubense tropical race 4. Sci. Rep. 9:8199.

Zhang, Y., He, J., Jia, L.-J., Yuan, T.-L., Zhang, D., Guo, Y., Wang, Y., and Tang, W.-H. 2016. Cellular tracking and gene profiling of Fusarium graminearum during maize stalk rot disease development elucidates its strategies in confronting phosphorus limitation in the host apoplast. PLoS Pathog 12:e1005485.

Zipfel, C., and Felix, G. 2005. Plants and animals: A different taste for microbes? Curr. Opin. Plant Biol. 8:353-360. 